\title{
Városi deszegregáció, társadalmilag heterogén lakóközösségek, társadalmi tőke - egy hazai városi szegregátum felszámolásának tapasztalatai
}

\section{The role of social capital in urban desegregation processes MÉREINÉ BERKI BOGLÁRKA, MÁLOVICS GYÖRGY}

\begin{abstract}
MÉREINÉ BERKI Boglárka: tudományos segédmunkatárs, Szegedi Tudományegyetem, Gazdaságtudományi Kar Kutatóközpont; 6722 Szeged, Kálvária sugárút 1.; mereine@eco.u-szeged.hu; https://orcid.org/0000-0002-6739-6893

MÁLOVICS György: egyetemi docens, Szegedi Tudományegyetem, Gazdaságtudományi Kar Kutatóközpont; 6722 Szeged, Kálvária sugárút 1.; gyorgy.malovics@eco.u-szeged.hu; https://orcid.org/0000-0002-6539-8588
\end{abstract}

KULCSSZAVAK: deszegregáció; társadalmilag heterogén lakóközösségek; társadalmi tőke; jóllét; roma

ABSZTRAKT: A mélyszegény, stigmatizált, szegregált roma közösségek életében a megkötő társadalmi tőke egyrészt a társadalmi mobilitás gátja, másrészt alapvető fontosságú az érintettek jólléte szempontjából. A tanulmány a társadalmi tőke különféle változataival és azok hatásaival specifikusan, egy olyan hazai deszegregációs folyamat elemzésén keresztül foglalkozik, amely (a tervek alapján legalábbis) társadalmilag heterogén lakóközösségek létrehozatalára irányul. Ebből kiindulva tanulmányunkban arra a kérdésre keressük a választ, hogy mi a társadalmi tőke szerepe a heterogén lakóközösségek létrehozására irányuló deszegregációs folyamatokban. Kutatásunk keretét egy részvételi akciókutatási (RAK) folyamat adja, melyen belül kvalitatív kutatási módszereket alkalmaztunk. Következtetésünk, hogy a társadalmi tőkének kulcsszerepe van mind a deszegregációs folyamat eredményeképpen létrejövő lakóközösségek heterogenitását, mind az érintettek jóllétének alakulását illetően. Sem a heterogén lakóközösségek létrejötte, sem a megnövekedett jóllét nem automatikus következmény, e célok megvalósulását alapvetően befolyásolják az érintett szegregált közösségek társadalmi tőkéjének jellemzői.

Boglárka MÉREINÉ BERKI: junior research fellow, Research Centre, Faculty of Economics and Business Administration, University of Szeged; Kálvária sugárút 1., H-6722 Szeged, Hungary; mereine@eco.u-szeged.hu; https://orcid.org/0000-0002-6739-6893

György MÁLOVICS: associate professor, Research Centre, Faculty of Economics and Business Administration, University of Szeged; Kálvária sugárút 1., H-6722 Szeged, Hungary; gyorgy.malovics@eco.u-szeged.hu; https://orcid.org/0000-0002-6539-8588

KEYWORDS: desegregation; socially heterogeneous neighbourhoods; social capital; well-being; Roma

ABSTRACT: Research has shown that recurrent socio-spatial segregation of Roma in Hungary and in Central and Eastern Europe is often related to ethnicity. Spatial segregation is a Janus-faced phenomenon: on the one hand it limits life opportunities, while it also provides resources and security for those affected by it. Social capital plays a significant role in this Janus-faced character of spatial segregation.

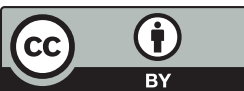


In order to eliminate spatial segregation, Hungarian local development policies have aimed to move segregated families into socially heterogeneous neighbourhoods. The assumption behind this goal is that spatial concentration of poverty has negative impacts on social mobility and wellbeing, partly because of the functioning of strong bonding relations.

As characteristics of social capital largely influence life in segregated Roma neighbourhoods, there is good reason to assume that these also influence the impact of desegregation processes on the life of stakeholders. Theoretically, spatial heterogeneity is assumed to have positive impact on social mobility by reducing bonding ties and supporting the coming about of bridging relations that provide access to resources and enhance opportunities for mobility and well-being. However, empirical research testing these theoretical considerations is missing in relation to Hungarian desegregation polices.

Our study empirically analyses this relationship based on the case of a desegregation process of a Hungarian urban segregated neighbourhood. We analyse how social capital influences (1) the actual realization of creating socially heterogeneous communities; and (2) changes in the well-being of formerly segregated residents. Our analysis is based on qualitative data (semistructured interviews and observations) that were collected within a wider participatory action research (PAR) process.

Our results indicate that social capital plays a significant role in both the actual coming about of socially heterogeneous neighbourhoods and changes in the well-being of the affected population. In order to serve the interests (well-being) of the affected population, Hungarian antisegregation planning should pay explicit attention to social capital linkages within segregated communities and their transformation during the desegregation processes.

\section{Bevezetés}

Magyarországon legkevesebb 300000 ember él szegregált körülmények közt, legalább 1633 etnikai alapon (is) szerveződő szegregátumban (Domokos, Herczeg 2010). A térbeli szegregáció egyfelől számos módon korlátozza az érintettek életlehetőségeit (Wacquant 2012), másfelől erőforrásokat is jelenthet számukra (Tóth et al. 2017). E kettősségben komoly szerepe van a társadalmi tőkének (Méreiné et al. 2017; Messing 2006; Messing, Molnár 2011a, b; Albert, Dávid 2006).

A hazai fejlesztéspolitikában a szegregáció egyértelműen nemkívánatos, felszámolandó jelenség (Méreiné, Málovics, Juhász 2017), az antiszegregációs tervezés egyik célja, hogy a szegregátumokat elhagyó családok integrált lakókörnyezetbe költözzenek. E mögött implicit módon a szegregáció és szegénységi koncentráció negatív mobilitási, jólléti, társadalmi hatásainak feltételezése húzódik meg. A kapcsolódó szakirodalom e célkitűzéshez a 'mixing policy' (Kearns et al. 2013; Silver 2013), 'social mix' (Bolt et al. 2010) 'mixed communities' (Lupton et al. 2009) fogalmakat kapcsolja, amelyeket magyarul összefoglalóan társadalmilag heterogén lakóközösségek létrehozásának nevezhetünk.

Ha a társadalmi tőke jellege nagymértékben befolyásolja a szegregátumokban zajló életet, úgy az antiszegregációs törekvésekre is hatással lehet. Tanulmányunkban e kapcsolatot elemezzük egy több mint tíz éve folyó részvételi akciókutatás (RAK) keretében összegyüjtött kvalitatív adatok alapján. A RAK helyszíne egy megyei jogú város egyik felszámolás alatt álló szegregátuma. Kutatásunk ar- 
ra irányul, hogy megértsük, mi a társadalmi tőke szerepe a heterogén lakóközösségek létrehozására irányuló antiszegregációs törekvések sikerességében. A sikeresség értelmezésünkben azt jelenti, hogy (1) társadalmilag heterogén lakóközösségek jönnek létre, illetve (2) hogy a folyamat eredményeképpen a korábban szegregáltan élő emberek/családok szubjektív jólléte is erősödik. ${ }^{1}$

\section{Szegregáció, antiszegregáció, társadalmilag heterogén lakóközösségek, társadalmi tőke}

A lakóhelyi szegregáció a társadalmi távolságok térbeli leképződése (Ladányi 2007). A nemzetközi szakirodalomban gyakrabban használják a "gettó” vagy „slum" megnevezést. Wacquant (2012) szerint gettóról akkor beszélhetünk, ha (1) az adott terület térben élesen elválik a település többi részétől; (2) az itt élőket a többségi társadalom stigmatizálja; (3) az itt élő családok nem saját döntésük alapján, hanem valamiféle kényszer hatására költöztek ide; (4) a többségi társadalomtól elkülönülő, párhuzamos intézményrendszert használnak. Tanulmányunkban a szegregáció fogalmának használatakor a gettó e definíciójából indulunk ki - az általunk megismert „,szegregátum” a nemzetközi „gettó” fogalom jellemzőivel bíró terület.

A hazai városfejlesztési dokumentumok kötelező részét képező antiszegregációs tervek a szegregációt egyértelműen felszámolandó jelenségnek tekintik, annak vélt negatív hatásai miatt (Méreiné, Málovics, Juhász 2017). A Városfejlesztési Kézikönyv a hazai szegregátumok vonatkozásában a deszegregációt tartja előremutató beavatkozási módnak (NFGM 2009). E személetben törekedni kell arra, hogy integrált, vegyes társadalmi összetételű lakóközösségek jöjjenek létre, vagyis a cél az, hogy az érintettek integrált lakókörnyezetbe költözzenek. Az ilyen beavatkozások mögött az a megfontolás húzódik, hogy a társadalmilag heterogén szomszédság elősegíti a társadalmi kohéziót, valamint jótékony hatással van az alacsony státuszú lakosság mobilitási esélyeire, köszönhetően az új szomszédsági kapcsolatokon keresztül hozzáférhetővé váló anyagi és nem anyagi erőforrások kölcsönös megosztásának.

A tudományos elemzésekben nincs egységes vélemény arról, hogy a társadalmilag heterogén lakóközösségek létrehozását kívánatos és hatékony fejlesztési stratégiának (Solon, Page, Duncan 2000; Ludwig, Duncan, Hirshfield 2001; Katz et al. 2001; Lupton et al. 2009; Kearns, Mason 2007), esetleg önmagában csekély haszonnal járó (Oreopoulos 2003; Silver et al. 2013; Cheshire 2009), bizonyos körülmények között pedig egyenesen káros (Mugnano, Palvarini 2013) beavatkozásnak tekinthetjük-e. Az empirikus kutatások többsége esettanulmányokat vesz górcső alá, és a vizsgált beavatkozások nagyban különböznek egymástól a beavatkozás előfeltételeit, folyamatát és hatásait illetően egyaránt (Galster, Andesson, Musterd 2010; Monk, Clarke, Tang 2011; Silver 2013; Jens, Duncan, Hirschfield 
2001; Bolt, Phillips, Van Kempen 2010; Oreopoulos 2003; Kearns, Forrest 2000). A szóban forgó tanulmányok elemzése során igyekeztünk feltárni azokat a tényezőket, amelyekre építve olyan megállapításokat tehetünk, amelyek előrevetíthetik egy ilyen beavatkozás hatásait, következményeit. Ezek a következők:

(1) A társadalmilag heterogén lakóközösségek létrehozása önmagában általában nem elegendő a várt pozitív hatások generálásához. Sok esetben konfliktusok kialakulásához, stigmatizációhoz, reszegregációhoz vezethet, így a különféle segítő-kísérő beavatkozások jelentősége kiemelkedően fontos.

(2) A társadalmilag heterogén lakóközösségek létrehozása sok szempont (dimenzió) mentén történhet - a nemzetközi gyakorlatban és elemzésekben gyakori például a lakástulajdon vonatkozásában fennálló birtokviszony (tenure mix) alapú heterogenitásra való törekvés. Ugyanakkor a birtokviszony nem minden esetben tükrözi az érintettek jövedelmi helyzetét, és a jövedelmi távolság nem minden esetben jelent kulturális távolságot is. Fontos tehát annak tisztázása, hogy mi alapján különítjük el az egyes csoportokat, amikor társadalmilag heterogén lakóközösségek létrehozására törekszünk, az elkülönítés szempontjának (dimenziójának) ugyanis komoly hatása lehet a beavatkozás sikerességére.

(3) Az etnikailag heterogén közösségek létrehozatalára irányuló beavatkozásoknak sokkal több buktatóval kell szembenézniük, mint a jövedelmi-, vagy birtokviszony-szempontúaknak.

(4) A társadalmilag heterogén lakóközösségek létrehozása elsősorban olyan közösségek esetén működik, ahol nincs éles etnikai, kulturális elkülönülés, illetve a jövedelmi rés sem túlzottan magas az egyes csoportok között.

(5) Végezetül eltérő eredményeket kaphatunk akkor, ha az értékelésnél pusztán jövedelmi szempontokat veszünk figyelembe, vagy ha jelentőséget tulajdonítunk egyéb nem-piaci, jólléti tényezőknek is.

A társadalmilag heterogén lakóközösségek létrehozása kapcsán a sikeresség elvárása mögött az a feltételezés húzódik meg, hogy különböző státuszú emberek olyan kapcsolatot alakítanak ki egymással a beavatkozás után, amely erőforrásként működik mind egyéni, mind társadalmi szinten. E feltételezések gyakorlati teljesülésének kérdését a társadalmi tőke vizsgálatán keresztül elemezzük.

\section{Társadalmi töke}

Kutatásunk szempontjából a társadalmi tőke azon megközelítéseit tekintjük relevánsnak, amelyek a társadalmi tőke típusaival, a hozzájuk társuló mechanizmusokkal, pozitív és negatív hatásokkal együttesen foglalkoznak (Woolcock, Narayan 2000; Putnam 1995; Füzér 2015; Gilchrist 2009; Messing 2006; Burt 2000). A külföldi és hazai kutatásokban, amelyek kifejezetten a gettókban/szegregált körülmények közt élők (köztük a romák) kapcsolati hálójával foglalkoznak, a társadal- 
mi tőke egyéni és közösségi erőforrásként egyaránt megjelenik (Albert, Dávid 2006; Messing 2006; Messing, Molnár 2011a,b; Cartwright, Sík, Svensson 2007).

A társadalmi kapcsolatok iránya, erőssége alapvetően befolyásolhatják cselekedeteinket, elérhető erőforrásainkat, vagy a társadalmi mobilitás lehetőségét. Ez alapján három társadalmi tőketípust különböztethetünk meg.

A megkötő társadalmi tőke ('bonding social capital') egy zárt közösségen belüli, belső szolidaritáson alapuló intenzív, külső kapcsolatoktól elzárt forma. A szegregált roma közösségeket, cigánytelepeket erősen jellemzik ezek a kapcsolatok (Albert, Dávid 2006; Tóth et al. 2017; Méreiné et al. 2017), amelyek bizalmon, szolidaritáson, reciprocitáson alapulnak (Messing, Molnár 2006). A zárt, homogén hálózat biztosítja a mindennapi túlélést és erőforrásként müködhet (Tóth et al. 2017), ugyanakkor mérsékeli a szegénységből való kitörés esélyét és erősen korlátozó lehet (Fehér, Virág 2014; Tóth et al. 2017); hatásai akár generációkon keresztül szerepet játszhatnak a szegénység konzerválásában, a társadalmi mobilitás korlátozásában.

A csoportok közötti átjárást a gyenge kötéseken alapuló áthidaló ('bridging'), illetve az összekapcsoló ('linking') társadalmi tőke szolgálják (Woolcock, Narayan 2000; Putnam 1993; Füzér 2015; Messing, Molnár 2011a, b; Gilchrist 2009). Az áthidaló társadalmi tőke a különböző társadalmi csoportokon átnyúló tőketípusként működik, ami lehetővé teszi a más csoportok erőforrásaihoz való hozzáférést, és távolabbi barátokhoz, ismerősökhöz, esetleg szomszédokhoz füződő kapcsolaton keresztül működik. Az összekapcsoló társadalmi tőke ugyancsak a különféle társadalmi osztályokon átívelő kapcsolatokat jelenti, amelyek az egyes embereket formális és informális, hierarchikusan elkülönülö, így az egyének felett különböző fokú hatalommal rendelkező szervezetek képviselőihez füzik (Messing, Molnár 2011b, Pretty 2003).

A társadalmi tőke utóbbi két típusa alkalmas arra, hogy az egymástól eltérő társadalmi csoportok nyitottá váljanak, elfogadják a különbözőséget, segítsék a szabad információáramlást, egyesítsék eltérő erőforrásaikat (Putnam 1993). Fontos szerepet játszhatnak továbbá az alacsonyabb státuszú csoportok társadalmi mobilitásában is. A legtöbb hazai kutatás arra az eredményre jutott, hogy a szegregátumokban élők kapcsolathálózatából gyakorlatilag hiányzik az áthidaló társadalmi tőke, és komolyan megkérdőjelezhető az összekapcsoló társadalmi tőke rendszerintegrációs hatékonysága is (Szalai 2002; Durst 2002; Ladányi, Szelényi 2004; Tóth et al. 2017; Méreiné et al. 2017). ${ }^{2}$ Néhány szerző újabban amellett érvel, hogy nem jó ennyire élesen elkülöníteni a megkötő és a társadalmi osztályokon átívelő társadalmi tőke fogalmait. Lényegében ugyanannak az éremnek a két oldaláról van szó, ezért szükséges e megközelítés újragondolása (Blokland, Noordhoff 2016; Blokland 2016). Ha e két tőkefajta megkülönböztetése élesen elválik, az magában hordozza az áthidaló és összekapcsoló kötések elégtelenségét. Ennek az az üzenete, hogy a csoport élesen elkülönül a többségi társadalomtól, határai jól láthatóak, törésvonal jelenik meg a „mi” és „ők” mentén ('insiders' vs. 
'outsiders'). Mások úgy tartják, hogy szembeállítás helyett érdemes egyfajta spektrumként tekinti e tőkefajtákra, s hogy a jelenség értelmezésére a társadalmi tőke fogalma helyett célravezetőbb a granovetteri erős és gyenge kötések koncepciójára építeni (Leonard, Onyx 2003). ${ }^{3}$ Eszerint egy kötés annál inkább gyengül, minél kevésbé terheli az egyént a reciprocitás kényszere, tehát a külső erőforrásokhoz való hozzáférésén túl e kötelezettség gyengülése is szerepet játszhat a mobilitás lehetőségében. A megosztás „kényszere” az elit és a középosztály esetében nem feltétlenül okoz gondot, valódi konzerváló ereje elsősorban olyan társadalmi csoportok esetében van, akik szűkösen férnek hozzá az erőforrásokhoz (Blokland, Noordhoff 2016). Fontos leszögezni, hogy e hivatkozott újabb tanulmányok olyan közösségek vizsgálatával foglalkoztak, amelyek ugyan szegénynek számítanak, azonban a mi esetünkkel szemben nem volt jellemző rájuk az éles etnikai elkülönülés, illetve amelyek a társadalmi tőkére elsősorban közösségi beavatkozásokon keresztül érkező, közösségi erőforrásként tekintenek (Blokland, Savage 2016; Blokland, Noordhoff 2016).

A mi tanulmányunkban a társadalmi tőke elsősorban individuális erőforrásként jelenik meg, és a közösséget éles etnikai elkülönülés jellemzi. Ezért továbbra is indokoltnak tartjuk, hogy az értelmezés keretét a társadalmi tőke különféle típusai jelentsék. A társadalmi tőke komolyan meghatározza a hazai roma szegregátumokban élők erőforrásait, életminőségét, mobilitási lehetőségeit, a társadalmilag heterogén lakóközösségek tervezett létrehozása kapcsán pedig a döntéshozók (ha más fogalmakat használnak is) az áthidaló társadalmi tőke spontán erősödésétől várják a pozitív hatásokat. Ugyanakkor nem készült még empirikus kutatás annak feltárására, hogy a megkötő, összekapcsoló és áthidaló társadalmi tőke hogyan befolyásolja a társadalmilag heterogén lakóközösségek létrehozására irányuló, köztük az ilyen típusú hazai antiszegregációs beavatkozások sikerességét. Az alábbiakban ezen összefüggést elemezzük egy hazai megyei jogú város szegregátumának felszámolási folyamatán keresztül.

\section{A kontextus}

Kutatásunk terepe egy megyei jogú város nagyobbik roma szegregátuma (a továbbiakban szegregátum), amely a városközponttól mintegy 1,5 kilométerre helyezkedik el. 2017 tavaszáig a szegregátumban 16 társasház állt, ebből 12 négylakásos és 4 háromlakásos épület volt.

A lakások között sok a komfort nélküli, egy 35-40 négyzetméteres lakásban gyakran heten-nyolcan élnek/éltek. A lakók lakhatási státusza különböző: magántulajdonos, bérlő, jogcím nélküli használó és önkényes lakásfoglaló egyaránt akad köztük. A 2011-es népszámlálási adatok szerint hivatalosan 217 fő lakott itt - a tényleges lakosok számát nehéz pontosan megállapítani, mivel sok a jogcím nélküli lakáshasználó, az ideiglenes beköltöző, illetve itt élő családtagjainál 
életvitelszerűen tartózkodó, ám máshova bejelentett lakos. Az átlagos iskolai végzettség alacsony, az itt élő/élt aktív korúak háromnegyede nem rendelkezik rendszeres munkajövedelemmel.

A szegregátum egyfajta menedékként is működik: a kívülről beköltöző, jogcím nélküli lakáshasználók száma egy, a városban 2005-ben történt telepfelszámolás (Málovics et al. 2019b) után jelentősen megugrott, az onnan kiköltözött családok közül sokan, elsősorban megélhetési okokból, illetve az új közösségbe való beilleszkedés nehézségei miatt, ide vándoroltak vissza. ${ }^{4}$

A település antiszegregációs tervei a telep teljes felszámolását tüzik ki célul 2007 és 2029 közt. A 2014-es terv leszögezi, hogy a családok elköltöztetése csak integrált lakókörnyezetbe történhet. Az „antiszegregáció” megkezdésének „halogatása" után, 2017 tavaszán gyorsuló ütemben indult el a telep felszámolása. Egy épület egy ütemben kerül kiürítésre, és amint ez megtörténik, azonnal elkezdődik a bontás. Eddig kilenc épületet bontottak le, ami 6 négylakásos és 3 háromlakásos épületet jelent (1. ábra). Az utolsó épület bontása (legalábbis a tanulmány benyújtásáig utolsó) 2019 nyarán történt meg. A telepfelszámolást az önkormányzat finanszírozza. A bontásra vonatkozóan nem készült forgatókönyv (ami látszik az antiszegregációs tervben megfogalmazott tervek és az események közötti ellentmondásokból is), ahogy a kötelezően beépítendo” „szoft” elemeket sem rögzítették. A folyamatból hiányzik a projektekre (kötelezően) vonatkozó stratégiai tervezés és elszámolási kötelezettség is, és a feltételek (például a kompenzáció esetében) is folyamatosan változnak. Ez egyfajta „ad hoc” jellegü döntéssorozatot eredményez, ugyanakkor a folyamat rugalmasságát is biztosítja. A tulajdonosok

\section{1. ábra: A szegregátum bontási folyamata 2020. áprilisig}

The process of the demolition until April 2020

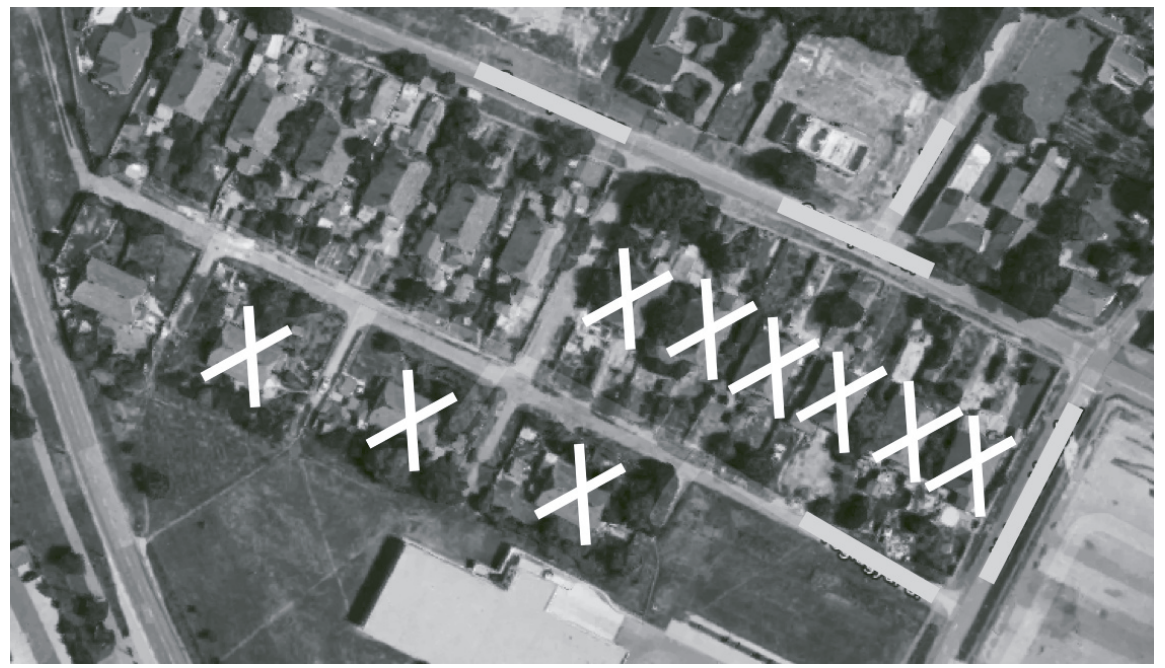

Forrás: Google Maps alapján saját szerkesztés 
kompenzációja például a folyamat előrehaladtával folyamatosan közelített a piaci feltételekhez, vagy amíg a döntéshozók eleinte nyilvánvalóvá tették, hogy a jogcím nélküli lakáshasználók nem kaphatnak kompenzációt, ez a szabály később enyhülni látszott.

Az itt élők eltérő lakhatási státusz alapján különböző kompenzációra számíthatnak azért, hogy elhagyják lakásukat. Az önkormányzati bérlakásban élő családok zömmel magasabb komfortfokozatú bérleménybe költözhettek a városon belül, kicsivel magasabb bérleti díjért. A tulajdonosoktól az önkormányzat megvásárolta a lakást: kezdetben egy új lakást vett számukra, később, mivel ez jelentősen meglassította a kiköltözés folyamatát, készpénzben fizette ki őket. A kompenzáció összege nem volt előre rögzítve. ${ }^{5} \mathrm{Az}$ önkényes lakásfoglalók és jogcím nélküli lakáshasználók eleinte semmiféle kompenzációra nem számíthattak; esetükben sokáig kizárólag elhelyezés nélküli kilakoltatásról beszélhettünk. A folyamat előrehaladtával azonban a városi önkormányzat a helyi Cigány Nemzetiségi Önkormányzattal (CNÖ) együttműködésben elkezdett krízislakásokat felajánlani azoknak a családoknak, amelyek esetében lehetségesnek tartották a többségi társadalomba való beilleszkedést (rendezett lakás és udvar, rendszeres jövedelem, iskolába, óvodába járó gyerekek).

A tulajdonosok és bérlők egyértelműen érdekeltek a deszegregációs folyamatban, hiszen ők azt egy jobb élet esélyeként értékelik. Az önkényes lakásfoglalók és jogcím nélküli lakáshasználók számára ugyanakkor a folyamat a legalapvetőbb egzisztenciális ellehetetlenülés veszélyét hordozza magában, ami komoly konfliktus forrása a szegregátumon belül.

A szétköltöztetést tehát semmiféle hivatalos integrációs program nem kíséri. Ugyanakkor az önkormányzat a tulajdonosok, bérlők, és az arra érdemesnek tartott jogcím nélküli használók és önkényes lakásfoglalók esetében a helyi CNÖ partnersége mellett törekszik a közös, személyre szabott megoldásokra, a családokkal külön-külön tárgyal, figyelembe veszi azok igényeit és lehetőségeit.

\section{Módszertan}

\section{Adatfelvétel, adatforrások}

Kutatásunk során kvalitatív módszereket alkalmaztunk, egy szélesebb körű megközelítés, a részvételi akciókutatás (RAK, 'participatory action research') keretén belül. Egy 2011-ben indult RAK folyamatban ${ }^{6}$ (Málovics et al. 2018) jelen tanulmány első szerzője 2015 óta rendszeres kapcsolatban van a szegregátumban élő és onnan elköltözött családok jelentős részével, és vezet rendszeresen kutatási naplót.

A RAK a kutatók és közösségek együttmüködése mellett érvel, amelynek segítségével megalapozott, és az érintett közösségek számára releváns tudás hozható létre (Coghlan, Brydon-Miller 2015). A kutatási folyamat része a tudás 
létrehozása mellett társadalmi változások elindítása is. Tanulmányunk szempontjából annak, hogy adatgyűjtésünk egy akció- és együttműködés-orientált folyamatba ágyazódik, legalább két szempontból van jelentősége.

Először is, saját tapasztalatunk - de általában is elmondható a RAK-ban -, hogy a közös akciók eredményeként a kutató-kutatott viszony partneri viszonnyá alakulhat, és a kialakuló bizalom lehetőséget teremt az őszinteségre és tabutémák megvitatására (Bradbury, Reason 2003). Ez a bizalmi kapcsolat elengedhetetlen az érvényes megfigyelésekhez egy ilyen kutatásban, ami egy zárt, stigmatizált közösségben zajlik, egy olyan ügy kapcsán, amelyben sokak egzisztenciális alapja forog kockán, amely megosztja a közösséget és komoly konfliktusok forrása. Másfelől, ahogyan Gordon és szerzőtársai (Gordon, Collins, Kearns 2017) fogalmaznak, a társadalmilag heterogén lakóközösségek létrehozására irányuló beavatkozások tudományos-kutatói értékelése kapcsán komoly hiány a szétköltöztetett emberek tapasztalatainak feltárása és bemutatása. Ennek oka leginkább az, hogy e tapasztalatok hagyományos társadalomkutatási eszközökkel (például kérdőív, interjú) a gyakorlatban nem/nehezen ragadhatók meg, hiszen a beavatkozások lényege éppen az, hogy az érintettek eltűnnek az adott területről (térben szétszóródnak). A RAK a hosszú távú kutató-érintett kapcsolatok kialakulásának elősegítése révén mindkét problémára választ ad.

Módszertanunk kapcsán episztemológiai szempontból fontos hangsúlyozni, hogy a RAK nyíltan vállalt értékekre épít: a társadalmi részvétel mellett fontosnak tartja a társadalmi igazságosság, az egyenlőség elősegítését, azaz a kutatás célja emancipatorikus (az érintettek megszabadítása az őket sújtó elnyomó feltételektől) (Málovics 2019). A tudásteremtés tehát a RAK-ban a hangnélküli, marginalizált társadalmi csoportok érdekében folyik. Ez a nyílt értékvezéreltség azonban nem feltétlenül jelent - a minden tudományos kutatásban valamilyen mértékben szükségszerűen megjelenőnél nagyobb - kutatói elfogultságot a megismerési folyamatban, annak ellenére, hogy a részvételi akciókutatók elismerik, hogy a beavatkozás (akciókomponens) ténylegesen komoly érzelmi elköteleződést eredményezhet, sőt, ez egyenesen kulcsfontosságú egy hosszabb RAK-folyamatban, amely hosszú távú, sokszor önkéntes elköteleződést igényel a szereplők részéről. Így „az akciókutatás alapvető kihívása a mély empátia és politikai elkötelezettség egyedülálló kombinálása a kritikai és reflexív kutatással, amelynek értelmében a kutatónak saját tapasztalataitól is egy lépés távolságot kell tartania" (Levin 2012, 134.) Azaz a RAK sikeréhez kutatói oldalon a közösségi aktivizmus és módszertani szigor egyensúlyának megtalálása szükséges. A módszertani szigort az adatfelvétel és -elemzés során a hagyományos társadalomkutatási standardok (adatrögzítés, strukturált elemzés, transzparencia stb.) alkalmazása biztosítja. Ami az „egy lépés távolságot” illeti, e tanulmány szerzői az elemzett folyamatoktól különböző távolságra állnak. Az első szerző folyamatosan jelen van a terepen, míg a második az antiszegregációs folyamatban a „reflexív kutató kolléga" szerepét vette föl. A távolságtartást biztosítják az egyes érintet- 
tekkel közös rendszeres reflexiós megbeszélések, az adatok többkörös, a szerzők által külön-külön elvégzett elemzése, valamint az érintettek bevonása a kutatásba. (Például az interjúfonalat egy korábban a szegregátumban élő, majd onnan elköltözött családdal közösen állítottuk össze, az eredményeket később visszavittük, majd közösen értékeltük.)

Mivel tanulmányunk esettanulmány jellegü (Flyvbjerg 2011), eredményeink csak korlátozottan általánosíthatók (például más antiszegregációs folyamatokkal kapcsolatban). Ezt csak tovább erősíti, hogy nem találtunk más, a jelen tanulmányban bemutatott folyamatokkal összevethető elemzést sem a hazai, sem a nemzetközi tudományos szakirodalomban, különösen nem a jelen elemzéshez hasonló fókusszal. Ez azonban nem pusztán a RAK sajátja; az alacsonyabb fokú megbízhatóság és magasabb (megítélésünk szerint a RAK esetében kiemelkedően magas) fokú érvényesség általában is jellemző a kvalitatív társadalomkutatási módszerekre.

A kutatási naplóban összegyűjtött információk mellett kétkörös adatfelvétel is történt. 15 félig strukturált interjút készítettünk 2016-ban, amikor még nem kezdődtek el a kiköltöztetések és a bontások, további 14 félig strukturált interjú készült el (7-7 interjú elköltözött interjúalanyokkal és olyanokkal, akik ekkor még a szegregátumban éltek) 2018-ban, amikor már az épületek közel felét lebontották. Ezek többsége csoportos interjú, ${ }^{7}$ így összesen 24 interjúalany fejtette ki számunkra véleményét (12 elköltözött, 12 maradó). Az interjúalanyok nagyjából fele mindkét interjús körben részt vett. Az interjúkat diktafonnal rögzítettük, majd szó szerint legépeltük őket, a kontextusról pedig jegyzeteket készítettünk. Az első körös (régi) interjúk esetében R1,2,3... kódokat használunk. A második körös (új) interjúknál megkülönböztettük azokat az interjúalanyokat, akik már elköltöztek (ÚK1,2,3...) azoktól, akik az interjú elkészítésének időpontjában még a szegregátumban éltek (ÚM1,2,3...).

\section{Adatelemzés8}

Az adatok felvétele és elemzése során számos olyan módszertani kihívással is küzdöttünk, amelyek a közösség egyes tagjainak diffúz lakhatási helyzetéből következnek. Ennek érzékeltetésére álljon itt X története.

Amikor először kerültünk X-szel kapcsolatba, hajléktalan volt. Később a párjával albérletben laktak, majd $\mathrm{Z}$, X testvére befogadta őket a szegregátumban lévő házuk udvarán álló garázsba (ahol azelőtt Z unokatestvére, A lakott, aki korábban hajléktalan volt, majd börtönbe került). X hol a párjával, hol nélküle élt a garázsban, amíg B ki nem költözött a házukból és egyúttal a szegregátumból is. Utána B üresen hagyott házában lakott önkényes lakásfoglalóként a párjával. Amikor ezt a házat lebontották, visszament $Z$-hez a garázsba, majd mikor azt is lebontották, akkor B-hez költözött, annak új lakásába, a párja nélkül. Onnan al- 
bérletbe (uzsorabérlet, lásd alább) ment, ahova megint ment vele a párja is. Amikor elárverezték a házat, ahol a szobát bérelték, Z-hez költözött, immár annak új lakásába (Z közben kiköltözött a szegregátumból). Az új ház egyébként $Z$ lányának, C-nek a nevén van, aki viszont nem ott él. X 2019 nyarán meghalt, élete végéig Z-nél maradt. Közben mindvégig ugyanazon a munkahelyen dolgozott.

A fenti(hez hasonló) lakhatási helyzetek gyakori jelenléte következtében már az elemzési egység megválasztása sem volt evidens. Végül elemzési egységnek a szegregátumban, majd - akiknél a kiköltözés bekövetkezett - azon kívül is tartósan együtt élő emberek csoportját választottuk (akik így lehetnek egyedül élő személyek, de akár sokfős családok is).

Komoly kihívást jelentett az is, hogy precíz kategóriákat képezzünk az érintettek lakhatási státuszának meghatározásakor. Ez ugyanis sok esetben nem állandó. Előfordult, hogy az interjú idején még bérlő volt az interjúalany, de néhány hétre rá jogcím nélküli lakáshasználóvá vált, mert felhalmozott adósságai miatt a helyi ingatlankezelő felbontotta vele a bérleti szerződést, így kompenzációra sem számíthat(ott) lakásáért cserébe. Gyakori jelenség továbbá, hogy (például szakítások, válások miatt) az adott háztartásban élő egyik fél legális státuszban a lakásban (illetve később az új lakóhelyen) marad, míg a másik elveszíti tulajdonát, jogilag hiába bérlője vagy tulajdonosa a szegregátumbeli lakásnak, illetve cserelakásnak. Előfordul az is, hogy a tulajdonos olyan család, esetleg kiskorú személy, aki valójában nem él a házban. Ez általában akkor alakul így, amikor a tényleges lakók komoly anyagi tartozást halmoznak föl, vagy a válások során vitás helyzet alakul ki. Ezekben az esetekben az érintettek lakhatási státuszának meghatározásakor nem a jogi, hanem a tényleges helyzetből indultunk ki, azt vettük figyelembe, hogy az érintettek valóban számíthattak-e kompenzációra az önkormányzattól.

Az elemzés során minden olyan tényezőt relevánsként kezeltünk, ami kapcsolódik a kutatási kérdéshez: a szétköltöz(tet)és és a társadalmi tőkében bekövetkező változások viszonyát, illetve ezek hatásait vizsgáltuk az érintettek jóllétére vonatkozóan.

Az interjúkat kvalitatív tartalomelemző szoftverrel (NViVo) elemeztük. Az új lakókörnyezet heterogenitása, valamint a jóllét változása kapcsán kialakított kategóriák az interjúszövegekből emelkedtek ki. A társadalmi tőke fő kategóriáit a tanulmány elején bemutatott szakirodalom alapján alakítottuk ki („megkötő”, „áthidaló” és „összekapcsoló” társadalmi tőke). Mindhárom tőketípus esetében kettős hatás rajzolódott ki. A megkötő társadalmi tőke egyfelől a szegregált körülményekhez alkalmazkodó, belső erőforrásként, másfelől a kitörést szinte ellehetetlenítő korlátként jelent meg, így elemzési kategóriáink is ehhez igazodtak. A társadalmi osztályokon átívelő kapcsolatok, vagyis az áthidaló, összekapcsoló társadalmi tőke megléte esetén szerepük és jellegük, hiányuk esetén a hiány okainak és következményeinek logikájából indultunk ki. Ez a logika már a tanulmányírást megelőzően, az évek óta tartó jelenlét és reflexiók során folyamatosan kristályo- 
sodott ki számunkra. Az elemzés során egyrészt ezekben a kategóriákban helyeztük el a szövegrészeket, másrészt egyéb megjelenő markáns kódok irányába is nyitottak maradtunk, illetve szükség esetén az előzetes kategóriákat további alkategóriákra bontottuk.

Elemzésünk során markánsan kirajzolódott a megkötő társadalmi tőke erodálódása, mint olyan tényező, amely az érintettek életét alapvetően befolyásolja. Ezt a jelenséget a mélyszegénységben élő (Magyarországon roma) közösségek esetében releváns hazai (Messing 2006, Messing, Molnár 2011a, b) és külföldi kutatások is alátámasztották (Blokland, Noordhoff 2008). ${ }^{9}$ E szövegrészekre új kategóriákat hoztunk létre (belső fragmentáció, eltávolodás, kapcsolatvákuum). Külön értelmeztük a kategóriákat a telepfelszámolás előtti állapotot (alapállapot), valamint a telepfelszámolás következményeit (deszegregáció hatása) illetően.

E szövegrészekre az elemzés logikája szerinti rendezés után először különkülön elemeztük, majd ezek összefüggéseire is igyekeztünk magyarázatot találni. A kutatási napló szoftveres elemzésére (egyelőre) nem került sor (több mint 450 oldalnyi kézzel írott szöveg), de az ebben megtalálható információkat beépítettük az elemzésbe.

Elemzésünk alapján elmondható, hogy a deszegregációs folyamat előmozdítását, javítását szolgáló, vagy az érintettek jóllétére közvetlen hatással bíró intézményi szintű, strukturális jelentőségü válasz nem mutatkozik. Ezek főleg személyek szintjén, félig informálisan jelennek meg, ugyanakkor az ennek kapcsán feltárt összefüggések szempontokkal szolgálhatnak a deszegregációs folyamatokat támogató facilitációs tevékenységekhez. Így e (összekapcsoló) tőketípussal kapcsolatos eredményeinket elsősorban ilyen szempontból mutatjuk be. Ha a deszegregáció társadalmi tőkére (és vica versa), és jóllétre gyakorolt hatásai kapcsán bizonytalansággal találkozunk, azt az elemzés során igyekszünk minél egyértelműbben (átláthatóan) megjeleníteni.

\section{Eredmények - társadalmi tőke és jóllét a szegregátumban}

\section{„Ha egybe tömörülnek, az se jó, de külön-külön is elveszünk egymás nélkül” - megkötö társadalmi tőke}

Korábbi publikációinkban elemeztük, hogy a szegregátum a benne élők számára a megkötő társadalmi tőkének köszönhetően kölcsönös anyagi, igencsak ellentmondásos pénzügyi erőforrásokat (uzsora), lakhatási, munkakeresési, gyermekfelügyelettel kapcsolatos stb. segítséget/erőforrást jelent, ahogy azt is, hogy a közösségben eltöltött idő több aspektusa is hozzájárul az érintettek szubjektív jóllétéhez (Tóth et al. 2017; Málovics et al. 2019a). 
Mindezek mellett a „nem materiális közösségi erőforrások” is jelentőséggel bírnak. Az érintettek konfliktusok esetén nem maradnak egyedül, a szegregátumban élö közösség biztosítja tagjai önbecsülését, mindez pedig erősíti biztonságérzetüket. Hat interjúban egyértelmüen kimondták, hogy jelentős „kulturális különbségek” vannak a „magyarok” és a cigányok között, ezért a romák jobban érzik magukat egymás között.

A megkötő társadalmi tőke azonban a szubjektív jóllétet csökkentő, társadalmi mobilitást korlátozó tényezőként is megjelenik. Az intim szféra hiánya, a „pletyka”, vagy a „szélsőséges egyenlősdi” (Tóth et al. 2017; Méreiné et al. 2017) problémái mellett a mobilitást korlátozó további tényező egyesek szerint a zárt, etnikailag homogén közösségben kialakuló sajátos közösségi kultúra, ami a szegregátumban élők viselkedését, beszédmódját, akár öltözködési szokásait is befolyásolhatja.

Bár még mindig nagyon erős szerep jut a megkötő társadalmi tőkének, a közösség széttöredezése már 2005 környékén elindult. A legelső törésvonal az újonnan betelepülők „reptériek” és az eredetileg ott élő családok között jelent meg, ez a reptéri szegregátum felszámolása után egy-két évvel már három-négy be(vissza)települő családot jelentett. 2017 tavaszától a deszegregációs (bontási) folyamat tovább mélyítette az árkokat, a hangsúly ekkor, a telepfelszámoláshoz kapcsolódó eltérő érdekek mentén a jogcím nélküli és a jogcímmel rendelkező lakáshasználók közötti ellentétre került. Tovább erodálta a közösséget a dizájnerdrogok elterjedése. ${ }^{10}$ „...ez a mérhetetlen sok drog (...)14-15 évesek is úgy crackelnek, füstölnek, rossz rájuk nézni (...) Nem látok motivációt már semmire sem. Megmondjam, hogy miért? Mert a drog (...), ha veszek egy sampont, becseréli herbálra." (ÚM4).

\section{„Ha arra mész, Bogi, csak úgy, mint te fehérbőrü, kérdezd már meg, van-e albérlet kiadó! - áthidaló társadalmi tőke}

A kevés áthidaló kapcsolat, amelyekkel bizonyos családok rendelkeznek, elsősorban társadalmilag integrált terekben jön létre. Egyes szakirodalmi források kiemelik ezzel kapcsolatban az intézményi környezet, az intézményi terek jelentőségét (Nast, Blokland 2014), ami egybecseng a mi eredményeinkkel is. Hét interjúban a munkahely jelentette ezt a teret, négy interjúalany a közeli bolt biztonsági őrével vagy eladójával került baráti kapcsolatba, további egy interjúalany említette az iskolai barátságokat, egy interjúalany az erdészt, akivel összebarátkozott (télen ingyen hozhatja a fát a közeli erdőből), egy pedig olyan kapcsolatokról számolt be, amelyeket egy vallási gyülekezetbe járva alakított ki. Maga a részvételi akciókutatási folyamat - melynek adatain jelen tanulmány alapul -, ezen belül a Patrónus Hálózat is fontos kapcsolatokat jelent, amelyeket minden érintett interjúalany említett.

A „kézzelfoghatóbb” segítség mellett (anyagi segítség, információk megosztása, papírok kitöltése, segítség hivatalos ügyekben, beajánlás legális munkahely- 
re), ezekben a kapcsolatokban az interjúalanyok nagy jelentőséget tulajdonítottak a mentális jólléttel kapcsolatos segítségnek is. A legfontosabbnak önbecsülésük növekedését tartották. Ezek a kapcsolatok a közösség többi tagjával szemben önbizalmat adnak, úgy érzik, hogy ezáltal ,jobbak”, valamilyen téren kiemelkedtek. Ezzel az érzéssel szinte minden esetben szorosan együtt jár a többiektől való megkülönböztetés vágya, a közösségből való kiválás érzése.

Az áthidaló társadalmi tőke esetenként érték- és viselkedésváltozást is okoz az érintett családoknál. Néhány interjúban említették, hogy változott az öltözködésük, beszédmódjuk, de volt olyan interjúalany, aki elmondta, a kapcsolatnak köszönhetően „célorientáltabbá” vált a gondolkodásmódja (például gyermekei taníttatása esetében).

Mindezek mellett jelen kutatás is alátámasztja, hogy a szegregált körülmények között élő családok csekély áthidaló társadalmi tőkével rendelkeznek, aminek oka elsősorban az etnikai törésvonal mentén keletkező távolság. Az etnikai stigmatizáció kiterjed a munka világára, de a lakhatásra is. „,...Romáknak nem adják ki szívesen lakást. Hiába van pénzed, rád néznek, és azt mondják, hogy betelt." (ÚM3) A stigmatizáció következménye a roma lakosság önbecsülésének csökkenése, a szégyenérzet, amely elzárkózást, a többségi társadalommal szembeni ellenállást eredményezhet. Végül a különböző kultúrából fakadó eltérő viselkedésmód ugyancsak megnehezíti az áthidaló kapcsolatok kialakítását „Nem rosszabb, vagy jobb, mert kulturáltak, csak más a mi kultúránk és megint más az ő kultúrájuk (...) Mindjárt azt mondják, hogy állandóan a veszekedés megy. Nem veszekedés, egyszerüen csak hangosabban beszélnek (....)." (ÚM5)

\section{„...jól jegyezd meg, aki a mai napig is, éveken keresztül foglalkozik a cigánysággal, az jó ember" - összekapcsoló társadalmi tóke}

Ahol az összekapcsoló társadalmi tőke megjelenik adatforrásainkban, az interjúalanyok nem intézményeket, hanem konkrét embereket említenek: volt és jelenlegi családsegíto, védőnők, iskolában dolgozó gyermekvédelmi szakember, volt és jelenlegi helyi képviselő és egy jogász, aki ingyen nyújt jogi segítséget néhány családnak. Ezek a nevek egymástól függetlenül több interjúban is visszaköszönnek és minden esetben pozitív kontextusban jelennek meg. Ezen kívül gyakran előkerül a helyi CNÖ képviselője.

Egyértelműen látszik, hogy elsősorban a személyekhez kötik a segítséget (kaput az elérhető erőforrásokhoz), nem pedig az intézményekhez. A személyeken túl az intézmény vagy meg sem jelenik, vagy ha igen, akkor általában negatív kontextusban, hátráltató tényezőként. E kapcsolatok vonatkozásában hasonló erőforrásokat találunk, mint az áthidaló társadalmi tőke esetében, azaz segítség a hivatalos ügyekben, papírok kitöltésében, ruhák és élelmiszerek adományozása. Minden ilyen kapcsolatban az „emberi szó” jelentőségét említették leggyakrabban, ami az érintettek önbecsülése és a különböző társadalmi csoportok között 
kialakuló bizalom szempontjából fontos. További fontos tényezőként jelenik meg az „ido”, hiszen egy hosszú távú bizalmi kapcsolat kialakulásához a személyes kompetenciákon túl elegendő időre is szükség van. Ez azonban nem minden esetben valósul meg (például a családsegítők személyét tudatosan, rendszeres időközönként cserélik), s ezért fontos erőforrásoktól, esetleges beavatkozási pontoktól eshetnek el az érintettek.

A néhány bizalmi kapcsolat mellett markáns tendencia, hogy az érintettek alapvető bizalmatlansággal viszonyulnak az intézményekhez, ami alapjaiban képes ellehetetleníteni az összekapcsoló társadalmi tőke kialakulását. E kontextusban az érintettek leggyakrabban a rendőrséget említették (6 interjú), legnagyobb problémájuk, hogy a szegregátumot „határon túli területként” (Harper 2009) kezeli a rendőrség. Ez egyrészt eltúlzott büntetési tételekben, másrészt abban ölt testet, hogy rendre elmarad a beavatkozás, amikor pedig szükség lenne rá. „Nem csináltak semmit. Úgy vannak vele, cigány, cigány, öljék meg egymást, annyival is kevesebb problémájuk van." (R4) Három interjú esetében a mentőkhöz kapcsolódó történetekben is megjelent, hogy a romákat úgy kezelik, mint akik a „határon túli” területhez tartoznak. Az intézmények képviselőitől tapasztalt lekezelő stílus tovább mélyítheti a társadalmi csoportok közötti szakadékot (9 említés). A bizalmatlanság az intézményi struktúra jellegzetességeire is visszavezethető. A családsegítővel kapcsolatban például beszéltek a gyakori személycserékről, vagy a félelemről, hogy a családsegítő akár a szülők megbüntetését vagy a gyermekek családból való kiemelését is kezdeményezheti (5 említés).

A bizalmatlanságot, s ebben az értelemben az intézmények diszfunkcionalitását támasztja alá a közösségen belüli párhuzamos intézmények jelenléte. (Egyebek mellett) a hitelpiac elérhetetlenségének következménye az uzsora, a rendőrség alkalmatlanságát jelzi a külső és belső konfliktusok rendezése önbíráskodással, ami az interjúalanyok többségének biztonságérzetet nyújt. A legális munkaerőpiac diszfunkcionalitását jelzi, hogy a közösség egy része tapasztalataink szerint a többségi társadalomhoz képest megengedőbb a különféle szürke/ fekete pénzkereseti tevékenységekkel szemben. Ez jelentheti a feketemunkát, de azt is, hogy részben megtűrik/elviselik az egyéb illegális tevékenységeket (akár a prostitúciót), ha a család mindennapi túlélése más módon, a strukturális elnyomás következtében az érintettek számára nem belátható perspektíva (kutatási napló). „...én nem is hibáztatom, mert persze egy anya, akinek gyerekei vannak, és az utolsó 100 forintját is, azt se tudja, mit vegyen belöle." (ÚE2 a prostitúcióról). Mivel a formális albérleti piac elérhetetlen, kialakult egy alternatív ingatlankereskedelmi hálózat, ahol a roma családok egymás között adják, veszik a (rendszerint alacsony komfortfokozatú) lakásokat, cserélik a bérleményeket. A hálózatban „ügynökök” is tevékenykednek, akiknek sikerdíja a „mita”, ami sikeres üzlet esetén a megvásárolt lakás árának kettő-négy százalékát jelenti (kutatási napló). 


\section{Eredmények - deszegregáció, társadalmilag heterogén lakóközösségek, társadalmi tőke és jóllét}

\section{Deszegregáció, társadalmi tőke, és társadalmilag heterogén lakóközösségek?}

A deszegregációs folyamat során a szegregátumbeli lakhatási helyzet meghatározza azt, hogy a kiköltözők ténylegesen meg tudják-e választani új lakóhelyüket. A tulajdonosok az ingatlanárak szabta korlátok között, de elvileg szabadon választhatják meg új lakhelyüket (tulajdonukat). A kompenzáció mértéke azonban némileg befolyásolja azt, hogy hol, milyen körülmények között tudnak maguknak lakást vásárolni. Ahogy azt a harmadik fejezetben bemutattuk, a kompenzáció összege folyamatosan emelkedett, de még az eddig ajánlott legmagasabb összeg is bőven elmarad attól, amelyből a tulajdonosok egy nagycsalád számára is megfelelő lakást tudnának maguknak vásárolni (jelenleg ez körülbelül egy másfél szobás felújítandó panellakás árának felel meg a város egyik lakótelepén). A tulajdonosok így vagy a város szélén, vagy más településen (ahol olcsóbbak az ingatlanárak) tudtak maguknak lakást vásárolni. Lehetőségük van továbbá olyan „cigányházakban” vagy a szegregátumhoz nagyon közel eső területeken lakást venni, ahova a középosztálybeliek nem szívesen költöznek be, így ezek árai alacsonyabbak. ${ }^{11} \mathrm{~A}$ bérlők esetében a lakóhely megválasztásának szabadságát az önkormányzati bérlakásállomány területi elhelyezkedése korlátozza, találunk azonban bérlakásokat a szegregátumhoz közel és távol is. Végül a jogcím nélküli lakáshasználók és önkényes lakásfoglalók többsége semmilyen kompenzációra nem számíthat, az ő esetükben az új lakhely megválasztásakor szegénységük és stigmatizált létük miatt kizárólag kényszerekről beszélhetünk.

A lakókörnyezet „integráltságát” két szempontból tartottuk érdemesnek megvizsgálni. Az új lakóhely heterogenitási fokának megítélésekor először is fontos, hogy a szegregátumból kiköltözők olyan épületbe/épületegyüttesbe költöztek-e, ahol már élnek roma családok (például olyan társasházba, ahol más lakásokban élnek már roma lakók). Másrészt az is perdöntő, hogy milyen messze költöztek a szegregátumtól. A szegregátumtól való távolság kapcsán a következőket fontos hangsúlyozni. Abban a városrészben, ahol a szegregátum is található, régóta nagyobb arányban élnek romák, mint a város többi részén (Rátkai 1997). A területet a többségi társadalom gyakran „stigmatizálja”, errefelé az ingatlanárak is alacsonyabbak (Rácz 2014). A területhez lazán kapcsolódnak további „csapásirányok", amelyek ugyan más városrészhez tartoznak, ám szintén magasabb a roma lakosság aránya, és a térhasználatban is szorosan kapcsolódnak a szegregátumhoz (közös boltok, közös játszótér és egyéb közösségi terek). Az elköltözött családok új lakóhelyének elhelyezkedését illetően figyelembe vettük ezeket a sajátosságokat (1. táblázat). Voltak egyértelmüen kategorizálható lakóhelyek, például, amikor csupán néhány utcára költöztek a szegregátumtól (közeli elhelyezkedés), vagy más településre, illetve jóval messzebb eső városrész- 
re (távoli elhelyezkedés). Azokat a családokat, akik a fent említett, a szegregátumhoz „csapásirányaként” kapcsolódó, ám attól némileg távolabb eső házba költöztek, a „viszonylag közel” kategóriába soroltuk, míg azokat, akik bár lehet, hogy szomszédos, ám a szegregátum kapcsolódásain (zömmel nem romák lakta területen) kívülre költöztek, a „távolabbi elhelyezkedés” kategóriába soroltuk.

A telepfelszámolás eddigi tapasztalatai alapján elmondható, hogy az integrált lakókörnyezetbe költözés célja nem valósul meg maradéktalanul (1. táblázat). Az öt kiköltözött és kompenzációra jogosult tulajdonos közül ketten a szegregátumhoz viszonylag közel költöztek, ahol vannak közvetlen roma szomszédjaik. Három család pedig a szegregátumtól (viszonylag) távolra költözött, olyan helyre, ahol nincs közvetlen roma szomszédság.

A cserebérleménnyel kompenzált bérlők nagy része új önkormányzati bérlakását olyan környezetben kapta, ahol főleg középosztálybeli szomszédság él (ötből négy család) (1. táblázat), egy család költözött olyan helyre, ahol van roma szomszédja. Az öt családból egy költözött a szegregátum közelébe, négyen a szegregátumtól „távolabb”.

A jogcím nélküli lakáshasználók és önkényes lakásfoglalók helyzetének követése különösen nehéz. Látókörünkben 14 ilyen család van, akik közül négyen átköltöztek a szegregátum még álló, üres épületeibe. Közülük hárman csak átmenetileg tartózkodnak itt, amikor távol vannak, akkor télen hajléktalanszállón, nyáron pedig az utcán vagy erdőkben élnek. Két család elköltözött a városból (Kiskunmajsára, Soltvadkertre), majd az egyik visszaköltözött a rokonokhoz, ismét önkényes lakásfoglalóként. Egy család a közeli „miniszegregátumban”12 vásárolt magának lakást, egy pedig olyan házba költözött, ahol már korábban is laktak romák, de kevésbé hordozza magán a miniszegregátum jegyeit, ugyanakkor uzsorabérlet-jelleget ${ }^{13}$ ölt. Egy édesanya önerőből albérletbe költözött iskolás fiával viszonylag közel, ám többségében nem roma szomszédság mellé. Egy másik édesanya a kislányával anyaszállóra került. Többen (egy pár, egy egyedülálló férfi, egy család) uzsorabérletben kaptak helyet. Két család a közelbe költözött, egyikük esetében nincs roma szomszédság, a másik pedig egy másik szegregátumbeli lakásba költözés, majd hajléktalanlét után végül egy közeli, roma szomszédokkal rendelkező házban kötött ki. Összességében elmondható tehát, hogy társadalmilag heterogén közösségek létrehozása mint deszegregációs stratégia jóformán csak a bérlők esetében valósult meg. Akiknek volt választási lehetőségük, azoknak egy része korlátozottan heterogén lakókörnyezetbe költözött, aminek okai egyrészt piaci korlátokban, másrészt a társadalmi tőkéhez kapcsolható mechanizmusokban gyökereznek (lásd alább), amelyek gyakran összefüggnek egymással. Sokaknak pedig nem volt érdemi választási lehetősége - ők nem heterogén lakókörnyezetbe „menekültek”. 


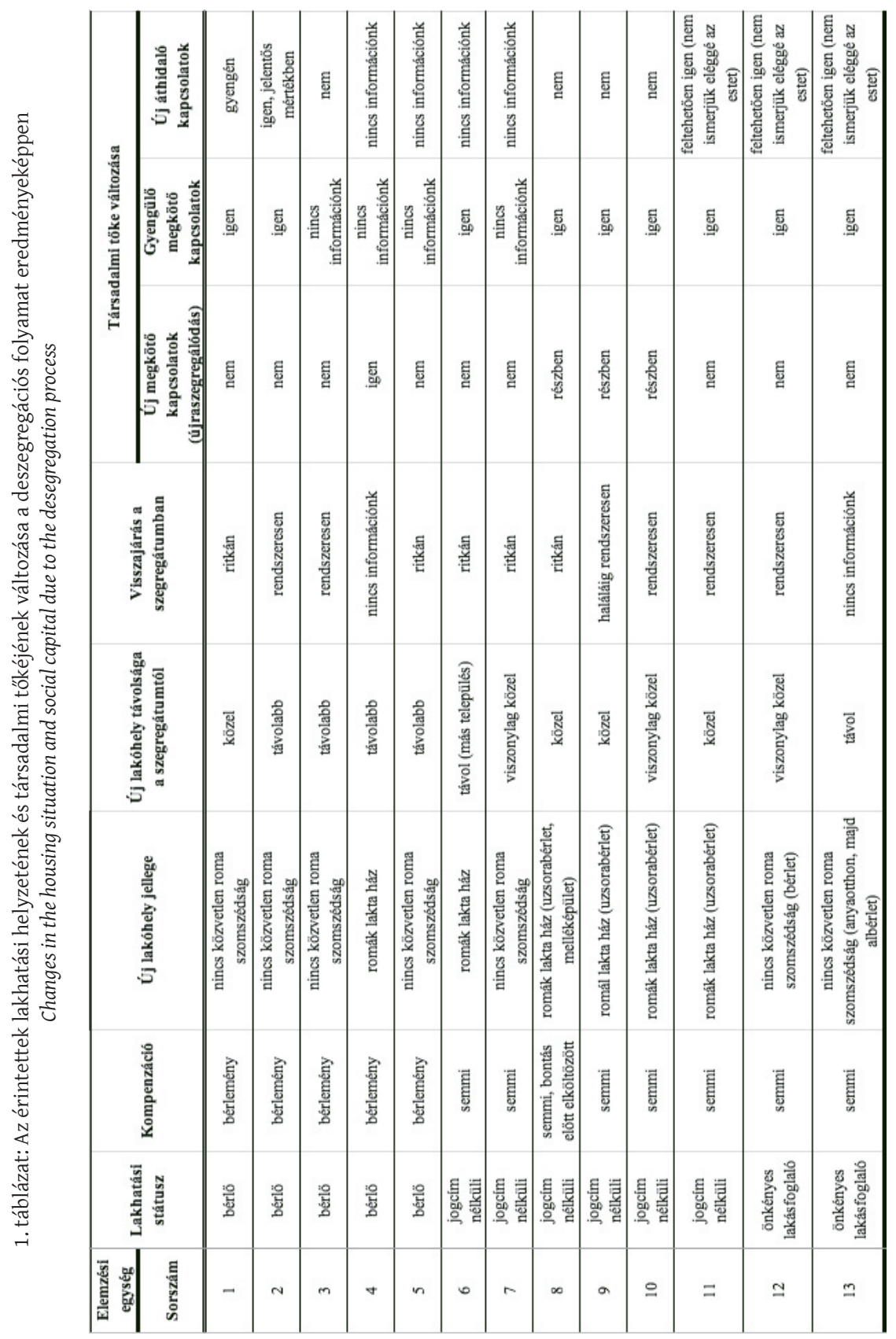




\begin{tabular}{|c|c|c|c|c|c|c|c|c|c|c|c|c|}
\hline 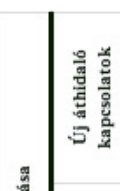 & 區 & 咅 & 皇 & 豆 & 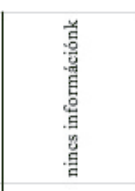 & 豆 & 西 & 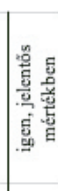 & 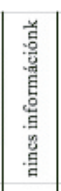 & 白 & $\mid \begin{array}{l}\text { 点 } \\
\text { 离 }\end{array}$ & 豆 \\
\hline 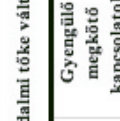 & . & 总 & 嵒 & . & 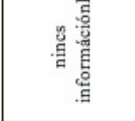 & 馬 & 豆 & 品 & 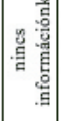 & 豆 & $\stackrel{\Xi}{g}$ & . \\
\hline$\left.\right|^{\mathrm{B}}$ & 总 & 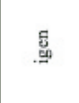 & 怘 & 点 & . ⿷匚ّ & 总 & 吕 & 営 & 豆 & 点 & $\begin{array}{l}5 \\
\frac{5}{8} \\
\frac{8}{2}\end{array}$ & 豆 \\
\hline 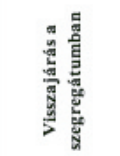 & 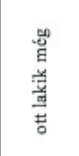 & 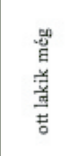 & 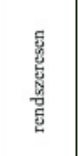 & 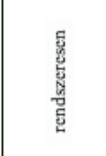 & 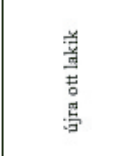 & 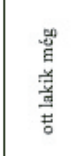 & 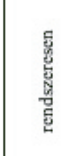 & 咅 & 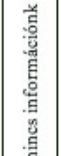 & 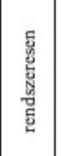 & 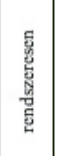 & 豆 \\
\hline 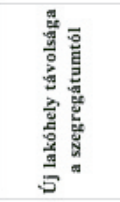 & 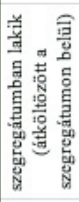 & 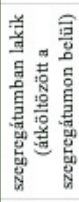 & 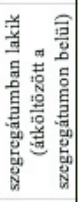 & 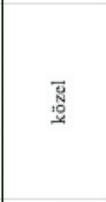 & 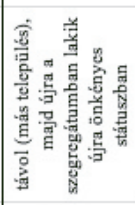 & 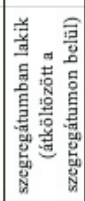 & 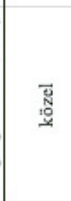 & $\overrightarrow{\mathrm{D}}$ & $\begin{array}{l}\text { 量 } \\
\text { : }\end{array}$ & 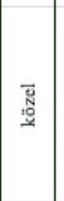 & 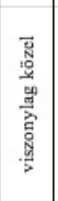 & $\vec{D}$ \\
\hline 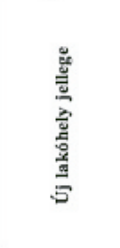 & 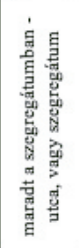 & 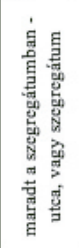 & 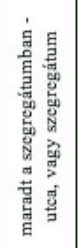 & 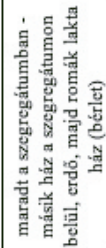 & 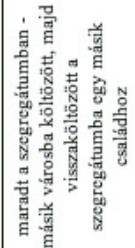 & 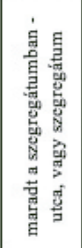 & 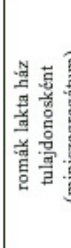 & 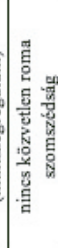 & 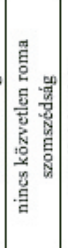 & 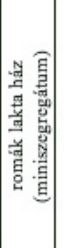 & 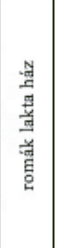 & 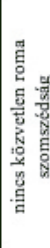 \\
\hline 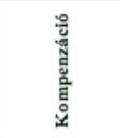 & 菂 & 且 & 息 & 焉 & 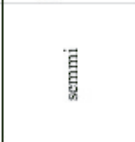 & 鼻 & 害 & $\begin{array}{l}\text { 憘 } \\
\text { 恶 } \\
\text { 总 }\end{array}$ & 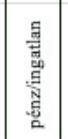 & 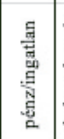 & 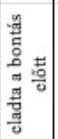 & 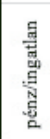 \\
\hline 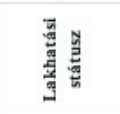 & 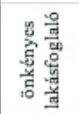 & 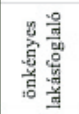 & 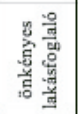 & 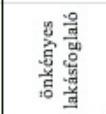 & 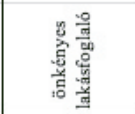 & 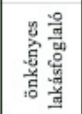 & 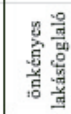 & 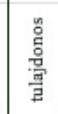 & 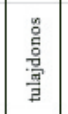 & $\begin{array}{l}\text { 总 } \\
\text { 亳 } \\
\text { 量 }\end{array}$ & 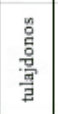 & 兽 \\
\hline 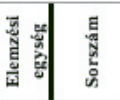 & \pm & $\cong$ & $\simeq$ & $=$ & $\cong$ & 2 & ते & $\vec{\sim}$ & | & ส & $\vec{N}$ & $\therefore$ \\
\hline
\end{tabular}




\title{
A társadalmi tóke változása a deszegregáció hatására
}

\author{
„,...ilyen közösségből nehéz kimenni, meg újrakezdeni az egészet” - a megköto”
} társadalmi töke erodálódása

A megkötő társadalmi tőke gyengüléséről, illetve elvesztéséről szinte minden interjúalany beszámolt. Interjúalanyaink beszámolói szerint leginkább az gyengíti a megkötő társadalmi tőkét, ha a családok kifejezetten heterogén környezetbe költöznek. Azok azonban, akik olyan társasházakba költöztek, ahol roma szomszédok vannak (nyolc ilyen család volt látókörünkben), két esetben nem beszéltek megkötő kapcsolataik gyengüléséről, illetve hat esetben beszámoltak arról, hogy új lakhelyükön a már ott élő roma családokkal új megkötő jellegü kapcsolataik alakultak ki.

Azok, akik a szegregátumtól távolabbra költöztek, kivétel nélkül megkötő kapcsolataik gyengüléséről számoltak be, és arról, hogy csak nagyon kis arányban voltak képesek új megkötő kapcsolatok kiépíteni. A szegregátumhoz közelebb költözők közül viszont volt, aki nem számolt be megkötő kapcsolatai erodálódásáról (noha a domináns tendencia e csoport esetében is a kapcsolatok gyengülése), és sokkal nagyobb arányban alakítottak ki új, megkötő jellegü kapcsolatokat. Az új lakóhely és a szegregátum közötti közelség jelentőségére utal az is, hogy azok közül, akik nem költöztek el, az interjúalanyok közel fele említette, hogy nem szeretne messze költözni a közösségtől.

Az elköltözők többsége mellett a maradók is beszámoltak a megkötő társadalmi tőke gyengüléséről. Láttuk, hogy a közösség már a bontások kezdete előtt sem volt egységes, a telepfelszámolás pedig tovább növelte a konfliktusokat, a közösség egyre inkább töredezetté válik. Emellett azok a családok, akiknek jobb esélyük volt a társadalmi mobilitásra, elsőként költözhettek el a szegregátumból rendezett lakhatási jogviszonyuknak, stabil munkahelyüknek, kiterjedtebb áthidaló és összekapcsoló társadalmi tőkéjüknek köszönhetően. Így a maradók között túlsúlyba kerültek azok a lakók, akik valamilyen problémával küzdenek (rendezetlen lakhatási jogviszony, extrém szegénység, mentális betegség, szenvedélybetegség). „Változott a közösség is a bontás óta. A veleje kitünt innen, azt mondom, hogy a ruskó maradt itt, az alja. Szorul a gyürü, mint a patkány, egyik lyukból be a másikba, ez van, bontják, és akkor ott a másik, menj oda és akkor ennyi." (ÚM4).

Fontos megemlíteni, ahogy arról már a korábbi fejezetekben is szó volt, hogy a közösség széttöredezése már korábban is elkezdődött, elsősorban egy régebbi deszegregációs beavatkozásnak köszönhetően, ezen kívül egyes hazai kutatások (Messing 2006; Messing, Molnár 2011a, b) szerint a társadalmi tőke fokozatos elvesztését olyan strukturális hatások is előidézik a roma közösségek esetében, mint például a rendszerváltás utáni tömeges munkanélküliség vagy az anyagi differenciálódás. Egyes nemzetközi kutatások eredményei alapján a sze- 
génységben élők eleve nem rendelkeznek olyan mértékủ és erősségű társadalmi tőkével, mint a középosztály (Blokland, Noordhoff 2016).

Tapasztalataink egyértelműen azt mutatják, hogy a deszegregációs beavatkozás jelentősen fokozta és felgyorsította a társadalmi tőke erodálódását. A bontás megkezdése előtt ugyan már láthatóak voltak a törésvonalak, tudomásunk szerint nem volt olyan érintett, aki a kapcsolatai teljes elvesztéséről, kapcsolatok hiányáról számolt volna be (kapcsolatvákuumba került volna). Amint a bontások elkezdődtek, egyesek olyan ütemben veszítették el megkötő társadalmi tőkéjüket, ahogy (jellemzően magasabb státuszú) rokonaik, barátaik elköltöztek közvetlen közelükből. Úgy tűnik, hogy ezt a veszteséget egyelőre sem intézményi keretek között (például utcai szociális szolgálat), sem azon kívül nem voltak képesek pótolni.

„...ott nem úgy kell élni. A magyar, az nem tudja, hogy kell alkalmazkodni a gyerekekhez." - az áthidaló kapcsolatok kialakulásának nehézségei

Az áthidaló társadalmi tőke jóval ritkábban jelenik meg az érintettek interpretációiban, mint a megkötő társadalmi tőke elvesztésének problémája. Hozzá kell tennünk, hogy az elköltözött családokat nem tudjuk teljes körüen követni, ami némileg gyengíti kutatásunk érvényességét e vonatkozásban. Akikről pontos információkat tudunk, azok közül két család a költözés óta jelentős mértékben gyarapította áthidaló társadalmi tőkéjét (1. táblázat). Mindkét család heterogén lakókörnyezetbe költözött, az egyik tulajdonosként egy másik településre, a másik bérlőként maradt a városban. Úgy tűnik, hogy áthidaló kapcsolataik egy része ennek az új, integrált környezetnek köszönhető, mivel ezeket középosztálybeli szomszédaikkal alakították ki. Új kapcsolatokra tettek szert továbbá azokban az integrált terekben, amelyeket eddig nem használtak (ez különösen arra a családra volt jellemző, amely másik településre költözött): a gyerekek óvodájában és iskolájában tanárokkal és szülőkkel, valamint bolti eladókkal, munkatársakkal kialakított kapcsolatok. Ezek valódi anyagi és szimbolikus erőforrásként működnek. E kapcsolatokon keresztül informálódnak különféle munkalehetőségekről, jutnak el gyerekeik iskolai táborokba, ezek által férnek hozzá szociális segítséghez, oktatási programokhoz, tanfolyamokhoz. Mindezzel párhuzamosan erősödött az önbecsülésük, fejlődtek a kommunikációs képességeik, és magabiztosabban igazodnak el a formális intézményrendszerben.

Fontos leszögeznünk, hogy ezek a családok már korábban is rendelkeztek áthidaló kapcsolatokkal, amelyek nagy része ugyan a költözéssel megszakadt, de nem esett nehezükre újabbak kiépítése a heterogén lakókörnyezetben (kutatási napló). Így a költözés csak elősegítette ezeknek a kapcsolatoknak a kialakítását, ám azt valójában sokkal inkább személyes kompetenciáiknak köszönhetően (jó kommunikációs készség, többségi társadalomhoz jobban illeszkedő életstílus) építették ki. 
Egy másik, korábbi bérlő család tapasztalatai kettősek. Egyrészt lettek középosztálybeli barátaik, viszont még mindig problémát jelent számukra, hogy a másfajta életmódhoz hozzászokjanak. Egyfajta távolságtartás mindkét fél részéről érezhető. „Lényegében, mikor ideköltöztem, akkor lettek magyar barátaim. (...) Az egyik szomszéd már föl akart jelenteni, ez a másik, a hangosabb nem szól, gondolom azért, mert ök is nagyon hangosak" (ÚE1).

Négy másik elköltözött család esetében vannak ugyan (korábbi szomszédoktól, barátoktól, rokonoktól, közösségi oldalakon a költözés utáni bejegyzésekből szerzett) információink arról, hogy új áthidaló kapcsolatokat alakítottak, ám annyira szoros kapcsolatban nem állunk velük, hogy ezek pontos körülményeit ismerhessük. A többi családról vagy szinte semmi információnk nincs e vonatkozásban, vagy azt látjuk, hogy nem vagy csak elvétve keletkeztek áthidaló kapcsolataik a költözés után (1. táblázat).

Az áthidaló kapcsolatok kialakításának nehézségeire utalva szinte minden interjúban említették, hogy vannak olyan családok, akik képtelenek lennének beilleszkedni integrált lakókörnyezetbe. Ezt részben azzal magyarázták, hogy e családok maguk is félnek a kulturális különbségektől, részben azzal, hogy a szóban forgó családok „eggyé váltak a hellyel”, emiatt nem tudnának máshol új életet kezdeni: „annyira berögződtek ebbe a miliőbe, hogy teljesen ellehetetlenülne a beilleszkedés a társadalomba" (ÚE6). A beilleszkedésre való képtelenség okaként elsősorban a többségi társadalomtól eltérő életmódot, a többségi szempontból deviánsnak tekintetett megélhetési stratégiákat, illetve a szenvedélybetegségeket nevezték meg.

„....megtanultuk kezelni azóta a helyzetet, amióta veled beszélünk” - az összekapcsoló társadalmi tóke hiánya

Terepi tapasztalataink során azt láttuk, hogy a döntéshozók tudatosan, szervezett módon nem építenek az összekapcsoló társadalmi tőkében rejlő potenciálra. A kapcsolatok elsősorban olyan személyekhez kötődnek (elsősorban egy családsegítő, egy védőnő és a helyi CNÖ elnöke), akik a folyamatot jóformán önkéntes munkában segítik, kötelezően elöírt munkakörükön túl. ${ }^{14}$ Ennek ellenére az érintettek szükségesnek tartanák az intézményi segítséget is (kutatási napló). Úgy érzik, hogy a formális intézmények magukra hagyták őket a folyamat alatt, nemhogy segítséget, de megfelelő tájékoztatást sem kapnak. Problémák adódnak például abból, hogy az érintettek sokszor a bontás pontos időpontját sem tudják. Ez elsősorban a jogcím nélküli lakáshasználók számára jelent gondot, mivel nekik a bontás után maguknak kell gondoskodni új lakóhelyükről.

Említettük már, hogy maga a RAK-folyamat, s ezen belül is a Patrónus Hálózat segítséget jelent. Elmondható, hogy azokban a családokban, ahol jelen volt a patrónus, viszonylag zökkenőmentesen zajlott a költözés. A patrónusok segítséget nyújtottak az elmaradt számlák kifizetésében, a költözésben, figyeltek arra, 
hogy az integrált lakókörnyezetben erősödjön a beköltözők önbizalma, közvetítettek a régi és új lakók között, igyekeztek hozzájárulni ahhoz, hogy az új környezetben kialakuljon a kölcsönös bizalom (kutatási napló). Ezek a kapcsolatok a költözés után nem szűntek meg. ${ }^{15}$

Az e tôketípussal kapcsolatos megfigyeléseink azt sugallják, hogy a deszegregációs folyamat érintettjeivel kapcsolatba kerülő intézményi munkatársaknak - 'street level bureaucrats' (May, Winter 2009) - kulcsszerepe lehet a deszegregációs folyamat facilitálásának (amennyiben van ilyen) minőségében is. Egyértelmü az is, hogy ahol ezeknek a személyeknek nagyobb a „mozgástere" (például családsegítőnek vagy védőnőnek), ott kialakulhat egyfajta erősebb bizalom, megmutatják az intézmények, szakpolitikák „emberi arcát” (Lipsky 1969), és adott esetben lehetőségük nyílhat a strukturális jellegű anomáliák enyhítésére is. Ahol viszont az intézményi képviselők jelenléte és mozgástere szűkösebb és/vagy erősen szabályokhoz kötött (például rendőrség esetében), ott kevésbé alakul ki ez a bizalom, inkább az ellenállás válik meghatározóvá.

Eredményeink nem teszik lehetővé, hogy a facilitáció intézményi körülményeivel kapcsolatban átfogó következtetéseket vonjunk le. Az azonban bizonyosnak látszik, hogy a sikeres (azaz az érintettek jóllétét és mobilitását potenciálisan segíto", konfliktusokat mérséklő) facilitáció szempontjából alapvető fontosságú a mélyszegény, stigmatizált, korábban szegregáltan élő romák életének, a szegregátum kulturális sajátosságainak, a stigmatizáció és elnyomás okozta élethelyzeteknek az alapos ismerete, valamint az empatikus, nyitott hozzáállás. Akárcsak a hosszú távú személyes kapcsolat az érintettekkel, ez tudja ugyanis megalapozni azt a fajta bizalmat, amely jó eséllyel előfeltétele a valós támogató-segítő kapcsolatok kialakulásának.

\section{A telepfelszámolás hatása a jóllétre a társadalmi tőke változásán keresztül}

Felmérni, hogy a deszegregáció okozta változások milyen hatást gyakorolnak az érintettek jóllétére, komoly kihívás. A már elköltözöttek ugyanis időről időre eltérő jólléti változásról számolnak be aktuális egzisztenciális helyzetüktől, családi körülményeiktől függően. ${ }^{16} \mathrm{~A}$ fenti megkötés mellett is kirajzolódik adatainkból néhány markáns tendencia. Egyfelől, a szegregátumot elhagyó, és tulajdonosként vagy bérlőként új ingatlanba költözők szinte kivétel nélkül életük javulásáról is beszámoltak. Ebben kulcsszerepet játszanak az új helyen meglévő jobb, rendezettebb lakáskörülmények, a biztonságosabb lakhatás, és az, hogy megszabadultak a szegregátum miliőjétől és néhány lakótárstól. Egy-két család kifejezetten a társadalmi mobilitás esélyeként, egyfajta szükséges „nagykorúvá válásként” értelmezi a szegregátumból való kiköltözést: úgy vélik, hogy a megkötő kötelékek elvesztése vagy gyengülése a rendszerintegráció előfeltétele. ők azok, akik már a bontások előtt is gyakran megfordultak integrált terekben, rendelkeztek áthidaló társadalmi tőkével. „(...) egyfajta biztonságot ad az embernek, csak az a baj, hogy ez a biztonság le is tud húzni, mert annyira hozzászoksz... nem bírsz a saját lábadra állni... Ez, 
hogy magamra vagyok utalva, egyfajta lendületet ad (...) szerintem ez az induló löket." (UE2). Emellett (4 interjúban említették) a költözés (az összekötő társadalmi tőke elvesztése) gyakran úgy jelenik meg, mint megszabadulás a negatív mintáktól, a lehúzó közegtől.

Emellett azonban ugyanezek az emberek/családok arról is beszámoltak, hogy „elmagányosodtak”, hiányoznak nekik a barátaik, a szegregátumban lakó családtagjaik. „A társaság nagyon fontos. Az emberek összetartanak. Közösségben nő fel az ember, ilyen közösségból nehéz kimenni, meg újra kezdeni az egészet" (ÚM2). Ezt az állítást támasztja alá (és enyhíti a hiányt), hogy az elköltözők többsége rendszeresen, de legalább időnként visszajár a szegregátumba, leginkább emberi kapcsolatai miatt.

A megkötő társadalmi tőke hiányát emellett az anyagi erőforrások elvesztéseként is érzékelték az interjúalanyok (5 interjú). „(...) széthullottunk. Ez végül is, minden a kilakoltatás. Előtte könnyebb volt, megbeszéltük, mikor mit, jött a fizetés, jó, gyerekek, ezt megvesszük, kész..." (ÚE4).

A költözés ellentmondásosan hat az érintettek önbecsülésére. Az új lakókörnyezet egyfelől az önbecsülés növekedését eredményezi: az érintettek megszabadultak számos területi és társadalmi stigmától, lakókörnyezetük emberhez méltóbb lett, „kiváltak”, megkülönböztetik magukat a szegregátumban maradt társaiktól. Ezzel párhuzamosan ugyanakkor sokszor úgy érzik, nem képesek megfelelni az integrált környezet elvárásainak, a középosztállyal szemben érzett kisebbségérzet a védett környezetből kiszakadva még intenzívebben rombolja az érintettek önbecsülését.

A miniszegregátumba költözők érzik magukat a legjobban. Ennek az az oka, hogy leginkább ők képesek megkötő kapcsolataik újjáépítésére, ami legalább részben biztosítja számukra a hozzáférést a materiális és nem materiális előnyökhöz. „Én nagyon örülök, hallod, hogy ide kerültem. Maga a környezet is már, meg a szomszédaim is nagyon aranyosak velem, segitünk egymáson, ha nekem nincs kávém, ad, ha neki nincs kávéja, én adok. Meg úgy, ha baj van, egymásra lehet itt is számítani” (ÚE4). A miniszegregátumba költözők sokkal kisebb mértékü „önbecsülés-veszteséget" szenvedtek el, mint integráltabb környezetbe költöző társaik (kutatási napló).

Míg az elköltözők különböző csoportjaiban tehát vegyes és valamelyest differenciált jólléti hatásokról számolhatunk be, addig a maradók közül szinte mindenki elveszítette eddigi kapcsolatait (főleg azok, akiknek nincs családjuk), ezáltal kapcsolatvákuumba kerültek. „Próbálok, de már nincs ember, akivel összefogok"(ÚM4). Az ő szubjektív jóllétüket kifejezetten negatívan érintette a deszegregációs folyamat (hiszen kompenzáció hiányában alapvető létbizonytalansággal néznek szembe). 


\section{Következtetések és további kutatási irányok}

Kutatási kérdésünk arra vonatkozott, hogy mi a társadalmi tőke szerepe a deszegregációs folyamatok sikerességében. Adataink elemzéséből az alábbi következtetéseket adhatjuk válaszként.

A társadalmi tőke alapvetően befolyásolja azt, hogy a deszegregációs folyamatok eredményeképpen létrejönnek-e a heterogén/integrált lakóközösségek. Esetünkben azoknak egy része, akiknek volt választási lehetőségük, eleve olyan új lakókörnyezetet kerestek vagy keresnek maguknak, ahol már élnek romák, nem függetlenül a megkötő társadalmi tőke által nyújtott materiális és nem materiális jólléti előnyöktől. Ez pedig egy reszegregációs folyamatot indított el. A piaci tényezők (elsősorban a lakásárak) szerepe sem elhanyagolható, az érintettek interpretációiban azonban ez alig jelenik meg, noha közvetett módon kapcsolódhatnak a társadalmi tőkéhez.

Ugyancsak reszegregációs folyamatot indít el, hogy több érintettnek, esetünkben a jogcím nélküli lakáshasználóknak, illetve önkényes lakásfoglalóknak - a kompenzáció hiánya, illetve társadalmi és egyéb tőkeformáinak alacsony szintje miatt - nincs lehetösége arra, hogy integrált/heterogén környezetbe költözzön. Esetükben deszegregáció helyett inkább kiköltöztetésről ('displacement') volt szó. ${ }^{17}$

Míg előbbi az érintettek kapcsolataiból, a szegregált közösség működéséből fakad, utóbbi egyértelműen a politikai döntéshozók által követett antiszegregációs stratégia, azaz a kompenzáció és elhelyezés nélküli kilakoltatás eredménye. Egy olyan program, amely ténylegesen törekszik társadalmilag heterogén lakóközösségek létrehozására, a szegregált közösség(ek) társadalmi tőkéhez kapcsolódó mechanizmusai miatt szükségszerüen komoly kihívásokkal néz szembe, hiszen az érintettek nem feltétlenül akarnak rögtön nagyon heterogén lakókörnyezetbe költözni. Ugyanakkor a program a jogszabályok számára láthatatlan lakosok negligálását praktikusan nem engedheti meg magának, hiszen ez önmagában is reszegregációhoz vezet. Személyes értékeink szerint ez önmagában is embertelen és nem csupán praktikusan, de morálisan is elfogadhatatlan hozzáállás és gyakorlat.

A heterogén lakóközösségek létrehozására irányuló deszegregációs folyamat egyértelműen romboló hatással volt mind a kiköltözők, mind a maradók megkötő társadalmi tőkéjére. Mindemellett nem látszik, hogy az új környezetben „automatikusan" létrejönnének áthidaló kapcsolatok. Kivételt azok jelentenek, akiknek már a kiköltözés előtt is voltak ilyen kapcsolataik, és rendelkeznek az ilyen típusú kapcsolatok kiépítése szempontjából előnyös kompetenciákkal. Azaz: az integrált környezetbe történő hirtelen kiköltözés az érintettek nagy többsége számára rendkívüli kihívást jelent.

A deszegregáció jólléti hatásai csoportonként eltérőek, ellentmondásosak, és szoros kapcsolatban állnak a társadalmi tőkében bekövetkezett változásokkal. Az elköltözők esetében a megemelkedett megélhetési költségek a megkötő kapcsolatok erodálódása miatt együtt járnak a materiális erőforrás-mennyiség csökkené- 
sével. Ehhez társul negatív jólléti hatásként a szintén a megkötő kapcsolatok gyengülése következtében bekövetkezo „elmagányosodás”. E jólléti veszteségek mellett azonban az elköltözőknél megjelenik egy komoly jólléti nyereség is: maguk mögött hagyják a szegregátum jelentette nyomorúságos lakhatási viszonyokat, illetve visszahúzó miliőt. Hasonló kettősséget mutat a kiköltözés hatása is az érintettek önbecsülésére.

A megfelelő lakhatást biztosító kompenzációban részesülő kiköltözők a deszegregációt esélynek tekintik egy jobb (magasabb jólléttel kecsegtető) életre. Azonban ez nem következik be automatikusan, hiszen számtalan kihívással, nehézséggel kell szembenézniük az új környezetben. A jogcím nélküli lakáshasználóknak és önkényes lakásfoglalóknak a deszegregációs folyamat nem más, mint „csendes” kilakoltatás ('displacement'), menedékük felszámolása, vagyis az egzisztenciális „megsemmisülés” veszélye.

A jóllét szempontjából elemzésünk alapján látható, hogy egyáltalán nem mindegy az, hogy az érintettek társadalmilag heterogén környezetbe költözneke vagy sem. Leginkább a miniszegregátumokba költözők szubjektív jólléte nőtt: náluk a szegregátum elhagyásának pozitív hatásai mellett nem, vagy sokkal kevésbé jelentkeztek a megkötő kapcsolatok leépüléséből fakadó negatív hatások. Ugyanakkor itt is nehezen alakulhatnak ki a jövőben áthidaló kapcsolatok, a megkötő kapcsolatok újjáépülése, a „reszegregáció” pedig magával hozhatja negatív jólléti következményeit is.

A maradók szubjektív jóllétét kifejezetten negatívan érintette a deszegregációs folyamat. Egyfelől ugyanis sokan kompenzáció hiányában alapvető létbizonytalansággal néznek szembe, másfelől elvesztették eddigi kapcsolataikat (föleg azok, akiknek nincs családjuk), kapcsolatvákuumba kerültek.

Kutatásunk megerősíti a vonatkozó szakirodalom megállapításait, miszerint a társadalmilag heterogén lakóközösségek irányított létrehozatala önmagában általában nem elegendő a várt pozitív hatások generálásához, különösen etnikailag heterogén, éles etnikai, kulturális elkülönüléssel, stigmatizációval jellemezhető esetekben. A konfliktusok, a stigmatizáció és reszegregáció elkerüléséhez a különféle segítö-kísérő beavatkozások rendkívül fontosak lennének. Az összekapcsoló társadalmi tőkével összefüggő eredményeink azt mutatják, hogy meghatározó a deszegregációs folyamat érintettjeivel kapcsolatba kerülő intézményi munkatársak szerepe. A facilitációs akkor lesz sikeres, ha az intézményi szereplők ismerik a mélyszegény, stigmatizált, korábban szegregáltan élő roma érintettek mindennapjait, a szegregátum kulturális sajátosságait, a stigmatizáció és elnyomás okozta élethelyzeteket, és empatikusan, nyitottan viszonyulnak az érintettekhez, akikkel hosszú távú személyes kapcsolatot alakítanak ki.

A beavatkozások érintettekre gyakorolt jólléti hatásai összetettek, azok anyagi és nem anyagi tényezőkre egyaránt kiterjednek. Ebből következően e hatások számbavételekor túl kell lépni a jövedelmi szempontok kizárólagosságán, ha komplex képet szeretnénk kapni a változásokról. 
Végül, tanulmányunk korlátai további kérdésekre hívják fel a figyelmet a társadalmilag heterogén lakóközösségek létrehozására irányuló (köztük antiszegregációs) beavatkozásokkal kapcsolatban. Fontos először is az idő dimenziója, mert egy hosszabb ideig tartó beavatkozás esetében a különböző időtávokban eltérő következtetésre juthatunk, mivel rendkívül komplex és olykor kiszámíthatatlan folyamatokról van szó. Megítélésünk szerint az idővel az emberi és intézményi kapcsolatok is változhatnak a beavatkozás eredményeképpen. Mindezek alapján állíthatjuk, hogy az antiszegregációs beavatkozások hatásértékelésénél szükség lenne hosszabb távú longitudinális, kohorsz jellegü kvalitatív és etnográfiai jellegü megfigyelési folyamatokra annak érdekében, hogy a beavatkozások hatásait mélyebben megértsük.

\section{Jegyzetek}

1 Jóllét ('well-being') alatt a közgazdaságtanban az anyagi jólétnél ('welfare') szélesebb értelemben vett életminőséget értjük. A közgazdaságtanban számos jóllételmélettel találkozunk (lásd Gébert 2015), jelen tanulmányban jóllét alatt az érintettek saját életminőségükre vonatkozó értékelését (szubjektív jóllétét) értjük.

2 Természetesen a magyarországi szegregátumok sokfélék lehetnek, ez alapján vannak kutatások, amelyek némileg ellentmondanak ennek. A romák migrációs stratégiáit vizsgálva Virág (2018) arra a következtetésre jutott, hogy csak a legalacsonyabb státuszú családokra jellemző ez a zártság, a magasabb státuszú roma családok rendelkeznek mozgósítható áthidaló társadalmi tőkével. Messing és Molnár (2011a, b) baranyai roma közösségeket vizsgálva arra a következtetésre jutott, hogy elsősorban a roma foglalkoztatás rendszerváltás utáni szűkülésének következményeként a romáknak nem csak áthidaló és összekapcsoló kötéseik, de minden mozgósítható kapcsolatuk gyengült (kapcsolatvákuum alakult ki).

3 Granovetter (1973) kapcsolatháló elmélete szerint a társadalmat erős és gyenge kötések ('strong and weak ties') szövik át. Az erős kötések általában zártak és csoporton belüliek, és bizonyos esetekben képesek védelmet nyújtani és erőforrást biztosítani a csoport tagjai számára. A felfelé irányuló társadalmi mobilitásban jelentős segítséget a különféle társadalmi csoportok között átívelő gyenge kötések képesek nyújtani.

4 A város szélén álló szegregátumot 2005-ben számolta fel az önkormányzat. Az itt élő családok nagyjából 1,5 millió forintot, vagy korábbi lakóhelyüktől 80-100 kilométerre lévő településeken álló házakat kaptak.

52017 tavaszán az első tulajdonos 3 millió forintos városszéli lakást és 2 millió forint felújításra fordítandó kompenzációt kapott. A következő család 7 millió forintért vásárolhatott házat egy, a korábbi lakhelyüktől 45 kilométerre elhelyezkedő településen, illetve az önkormányzat átvállalta tőlük a 250 ezer forintos közösköltség-tartozásukat. 2018-ban 7,5 millió forint készpénzt kapott szegregátumbeli lakásáért cserébe a következő kiköltöző család, majd 2019-ben 9, később 10 millió forintos kompenzációt kaptak az elköltöző tulajdonosok. Jelenleg (tudomásunk szerint) 15 millió forintos kompenzációt ajánlott az önkormányzat a még szegregátumban élő tulajdonosnak. A jelenlegi ingatlanárak mellett ez körülbelül egy másfél szobás, felújítandó, lakótelepi panellakás ára a városban. Az ingatlanárak a városban nem emelkedtek olyan mértékben, mint a kompenzáció összege, azt (a helyi CNÖ közbenjárásának is köszönhetően) fokozatosan igazították az ilyen típusú tulajdonok áraihoz.

6 A RAK folyamatában például tanodák jöttek létre (az érintettek bevonásával), a helyi CNÖ vezetőjének hangja fokozatosan erősödött (jelenleg már partnerként tárgyal vele az önkormányzat), létrejött egy alulról szerveződo” „Patrónus Hálózat”, amelynek keretében középosztálybeli, 
értelmiségi családok kerülnek kapcsolatba szegregátumbeli, mélyszegény, roma családokkal. A tanulmány mindkét szerzője aktív tagja a hálózatnak, kapcsolatuk a támogatott családokkal jóformán napi rendszerességű. (Lásd ehhez: Málovics et al. 2018; Méreiné 2017.)

$7 \quad$ Komoly módszertani kihívást jelentett, hogy találjunk egy nyugodt környezetet az interjú készítésére. A beszélgetések alatt rendszerint jöttek-mentek a rokonok, vendégek.

8 Jelen elemzésben legalább két fontos dologra nem térünk ki, az elemzés fókuszának megtartása érdekében. Először is, a döntéshozók (beavatkozók) az itt is elemzett jellegü beavatkozásokat a közvéleménynek szóló kommunikációban a társadalmi igazságosságra való törekvéssel indokolják, nyilvánvaló, hogy ettől a valós motivációk eltérhetnek (lásd nemzetközi kontextusban Uitemark (2003) munkáját). Jelen esetben például a szegregátum területe a város egyik (ha nem az) utolsó nagy, városközponthoz közel fekvő, tehát nagyon értékes ingatlana. Ez a körülmény, valamint az antiszegregációs terv végrehajtásának halogatása tíz évig, majd az 2017-ben bekövetkező felgyorsulása arra enged következtetni, hogy az érintettek jóllétén (mint döntéshozói retorikán) kívül elképzelhető, hogy más okok (például ingatlanpiaci folyamatok, befektetők) is állnak az antiszegregációs beavatkozás hátterében. Nem csoda, hogy a szegregátum lakosainak körében is számos pletyka terjed a területre tervezett lakóparkról vagy éppen fürdőkomplexumról. És bár mindez jelenleg nem több puszta spekulációnál, arra mindenképpen rávilágít, hogy a városi ingatlanpiaci folyamatok alapvetően befolyásolhatják a területhasználattal kapcsolatos igényeket, így az antiszegregáció kutatásakor érdemes lehet ezeket is megvizsgálni.

Másodszor, jelen tanulmányban az érintettek saját jóllétérzetének feltárására és megértésére koncentráltunk, ez azonban nem jelenti azt, hogy ne lenne helye a társadalmilag heterogén lakóközösségek létrehozása kapcsán is annak a húsbavágó kritikának, amely szerint e beavatkozások kolonizáló jellegűek (Gordon, Collins, Kearns 2017). Ahogyan Lees $(2008,2463$.) fogalmaz, e beavatkozások a középosztálybeli, közepes jövedelmű csoportokat teszik meg (konstruálják) „természetesnek”, ezáltal implicit módon azt sugallják: mindannyiunknak arra kellene vágynunk és törekednünk, hogy a középosztályhoz tartozzunk. Ugyanakkor kutatóként - az érintetti perspektíva legitimitásának elismerése mellett - egy ilyen megközelítés meglehetősen problematikus, ha más miatt nem is, minimum a „fejlett középosztálybeli” életmódok/életstílusok elnyomó jellege miatt - amely mind a szegény országokban élö tömegek, mind pedig a természeti környezet irányában egyértelmüen fennáll.

9 Hazai kontextusban a „kapcsolatvákuum” fogalmát, a nemzetközi szakirodalomban a 'draining social capital' kifejezést találtuk a jelenség megnevezésére.

10 Ezek megjelenése az érintett családok elmondása alapján nagyjából egybeesik „reptériek” betelepülésével, de a probléma az elmúlt 2-3 évben vált olyan mértékűvé, hogy sajtónyilvánosságot is kapott.

11 Látható, hogy a belső kapcsolatok és a külső piaci tényezők együttesen hatnak a reszegregáció irányába. Az érintettek interpretációi erősebben kapcsolódnak a belső tényezőkhöz (társadalmi tőke), emellett természetesen látjuk, hogy a romák lakta területek, a „cigányházak” alacsonyabb árai miatt a piaci tényezőknek is szerep jut, ami egyébként a többségi társadalomtól való távolságból is eredeztethető, amely mögött egyéb, nem pusztán piaci tényezők is állnak.

12 Egy-két romák lakta ház már-már miniszegregátumként funkcionál. Nem romák egyáltalán nem, vagy csak nagyon kevesen lakják, a lakosok életvitele alig tér el a szegregátumban jellemző élettől. Ezek a házak a többségi társadalom szemében egyértelműen stigmatizáltak, „cigányházakként" ismertek, ahol egyre nagyobb a roma lakosság koncentrációja.

13 Ők olyan bérleménybe kényszerülnek, ahol félszobát, fészert, ágyat (vagy akár gardrobe szekrényt) adnak bérbe lakhatási célból jóval piaci ár fölött (60-70 ezer forint feketén). Egy családi házban gyakran 9-10 család is él együtt, osztozva egy konyhán és egy fürdőszobán.

14 Segítenek például a költözésben, hivatalos papírok kitöltésében, bútorok beszerzésében.

15 Bár ezt a kapcsolatot itt tárgyaljuk, nem teljesen világos, hogy melyik tőketípusba sorolható. Társadalmi osztályokon átívelő kapcsolatokról van szó, azonban a patrónust sokszor családtagként kezelik (s van, hogy valóban azzá vált keresztszülőség révén). Az sem egyértelmű, hogy intézményen belüli vagy intézményen kívüli kapcsolatról beszélünk-e, hiszen a hálózat nem része egyetlen formális intézménynek sem, viszont nem spontán módon jött létre (például úgy, 
hogy szomszédokká váltak, vagy találkoztak egy munkahelyen), hanem a kezdeteknél szervezetten köti össze a hálózat az „új” családokat, akkor még ismeretlenként.

16 E módszertani kihívás, azaz a megkérdezés időpontjának hatása az eredményekre, általában is jellemző a szubjektív jóllét kutatására (lásd Krueger, Schkade 2008), ami egyben azt is jelenti, hogy egy hagyományos, egyszeri adatfelvételen alapuló (kvalitatív vagy kvantitatív) megközelítés itt igen félrevezető lehet.

17 A 'displacement' egyre gyakrabban tárgyalt téma a városföldrajz irodalmában, a társadalmi és térbeli igazságosság témaköréhez kapcsolódva. Gyakorlatilag a kényszerített kiköltöztetést jelenti, ám a kényszer mértéke egyfajta skálán mozog (például kiköltöztetés természeti katasztrófa, háború miatt vs. telepfelszámolás) (Elliot-Cooper et al. 2019). Ezért, bár fentebbi állításunk, miszerint a tulajdonosok és bérlők esetében deszegregációról, nem pedig kényszerített kiköltöztetésről beszélhetünk, megállja a helyét, valószínűleg árnyalná ezt az állítást az ilyen helyzetekben jellemző hatalmi egyenlőtlenségekre (Mihály 2019) reflektáló kritikai elemzés. Elég csak arra gondolni, hogy a tulajdonosok és bérlők nagyrészt a korábbi helyi fejlesztéspolitikai folyamatok (reptér felszámolása, szegregátumbeli közszolgáltatások hiánya) eredményeképpen szeretnék mindenképpen elhagyni a szegregátumot.

\section{Irodalom}

Albert F., Dávid B. (2006): A kapcsolati tőke dimenziói etnikai metszetben. In: Kolosi T., Tóth I. Gy., Vukovich Gy. (szerk.): Társadalmi riport. Tárki, Budapest, 351-372. https://doi.org/ 10.18030/ socio.hu.2015.4.1

Blokland, T., Van Eijk, G. (2010): Do People Who Like Diversity Practice Diversity in Neighbourhood Life? Neighbourhood Use and the Social Networks of 'Diversity- Seekers' in a Mixed Neighbourhood in the Netherlands. Journal of Ethnic and Migration Studies, 2., 313-332. https:// doi.org/10.1080/13691830903387436

Blokland, T., Savage, M. (2016): Social Capital and Networked Urbanism. In: Blokland, T., Savage, M. (eds).: Networked Urbanism - Social Capital in the City. Routledge, London, New York https:// doi.org/10.4324/9781315597805

Blokland, T., Noordhoff, F. (2016): The Weakness of Weak Ties: Social Capital to Get Ahead Among the Urban Poor in Rotterdam and Amsterdam. In: Blokland, T., Savage, M. (eds.): Networked Urbanism - Social Capital in the City. Routledge, London, New York https://doi.org/10.4324/9781315597805

Blokland, T. (2016): Gardening with a Little Help from Your (Middle Class) Friends: Bridging Social Capital Across Race and Class in a Mixed Neighbourhood. In: Blokland, T., Savage, M. (eds.): Networked Urbanism - Social Capital in the City. Routledge, London, New York https://doi.org/ 10.4324/9781315597805

Bolt, G., Phillips D., Van Kempen R. (2010): Housing Policy, (De)segregation and Social Mixing: An International Perspective, Housing Studies, 2., 129-135. https://doi.org/10.1080/026730 30903564838

Bradbury, H., Reason P. (2003): Action Research. An Opportunuty for Revitalizing Research Purpose and Practices. Qualitative Social Work, 2., 155-175. https://doi.org/10.1177/1473325003002002003

Burt, R. S. (2000): The Network Structure of Social Capital. In: Sutton, R.I., Straw, B.M. (eds.): Research in Organisational Behaviour. JAI Press, Greenwich, 345-423. https://doi.org/10.1016/S0191-3085(00)22009-1

Cartwright, A., Sik, E., Svensson, S. (2008): Social capital and the integration of minorities and immigrants in Hungary. Working Paper, Central European University, Budapest https://doi.org/10.5565/ rev/grafowp. 34

Cheshire, P. (2009): Policies for mixed communities: faith-based displacement activity? International Regional Science Review, 3., 343-375. https://doi.org/10.1177/0160017609336080

Coghlan, D., Brydon-Miller, M. (2015): The SAGE Encyclopedia of Acton Reserch, Routledge, London https://doi.org/10.4135/9781446294406 
Domokos V., Herczeg B. (2010): Terra Incognita: magyarországi szegény és cigánytelepek felmérése - első eredmények. Szociológiai Szemle, 3., 82-99.

Durst J. (2002): "Innen az ember jobb, hogyha meg is szabadul”. Adalékok egy kisfalusi cigányközösség szegénységéhez. Esély, 4., 99-201. http://www.esely.org/kiadvanyok/2002_4/DURST.pdf (Letöltés: 2019. november 5.)

Elliot-Cooper, A., Hubbard, P., Lees, L. (2019): Moving beyond Marcuse: Gentrification, displacement and the violence of un-homing. Progress in Human Geography https://doi.org/10.1177/0309132519830511

Fehér K., Virág T. (2014): Élet egy kisváros peremén. Tér és Társadalom, 3., 55-65. https://doi.org/ 10.17649/TET.28.3.2574

Flyvbjerg, B. (2011): Case Study. In: Denzin, N. K., Lindoln, Y. S. (eds.): The Sage Handbook of Qualitative Research. Thousand Oaks, 301-316.

Füzér K. (2015): A bizalom társadalomelmélete és a társadalmi tőke szociológiaelmélete. Századvég (Társadalmi Tőke Különszám), 4., 5-18.

Galster, G., Andersson, R., Musterd, S. (2010): Who is affected by neighbourhood income mix? Gender, age, family, employmnet and income differences. Urban Studies, 14., 2915-2944. https://doi.org/10.1177/0042098009360233

Gébert J. (2015): Mit is kell fenntartani? Fenntarthatóság a képességszemlélet perspektívájából. Közgazdasági Szemle, 62., 972-989. https://doi.org/10.18414/KSZ.2015.9.972

Gilchrist A. (2009): The Well-Connected Community: A Networking Approach to Community Development. The Policy Press, Bristol https://doi.org/10.1332/policypress/9781847420565.001.0001

Gordon, R., Collins, F. L., Kearns, R. (2017): 'It is the people that have made Glen Innes': State-led gentrification and the reconfiguration of urban life in Auckland. International Journal of Urban and Regional Research, 5., 767-785. https://doi.org/10.1111/1468-2427.12567

Granovetter, M. S. (1973): The strength of weak ties. American Journal of Sociology 78., 1360-1380. https://doi.org/10.1086/225469

Harper, K., Steger, T., Filcak, R. (2009): Environmental Justice and Roma Communities in Central and Eastern Europe. Environmental Policy and Governance, 4., 251-268. https://doi.org/10.1002/eet.511

Jens, L., Duncan, G., Hirshfield, P. (2001): Urban Poverty and Juvenile Crime: Evidence from a Randomized Housing-Mobility Experiment. Quarterly Journal of Economics, 116., 655-680. https://doi.org/ 10.1162/00335530151144122

Katz, L. F., Jeffrey, R. K., Jeffrey, B. L. (2001): Moving to Opportunity in Boston: Early Results of a Randomized Mobility Experiment. Quarterly Journal of Economics, 116., 607-654. https://doi.org/ $10.1162 / 00335530151144113$

Kearns, A., Forrest, R. (2000): Social cohesion and multilevel urban governance. Urban Studies, 5-6., 328-339. https://doi.org/10.1080/00420980050011208

Kearns, A., Mason, P. (2007): Mixed Tenure Communities and Neighbourhood Quality. Housing Studies, 5., 661-691. https://doi.org/10.1080/02673030701474628

Kearns, A., McKee, M. J., Sautkina, E., Cox, J., Bond, L. (2013): How to mix? Spatial configurations, modes of production and resident perceptions of mixed tenure neighbourhoods. Cities, 35., 397-408. https://doi.org/10.1016/j.cities.2013.03.005

Krueger, A .B., Schkade, D. A. (2008): The Reliability of Subjective Well-Being Measures. J Public Econ, 8-9., 1833-1845. https://doi.org/10.1016/j.jpubeco.2007.12.015

Ladányi J. (2007): Az antiszegregációs programok szükségességéről és lehetőségeiről. Kritika, 10., 2-4.

Lees, L. (2008): Gentrification and Social Mixing. Towards an Inclusive Urban Renaissance. Urban Studies, 12., 2449-2470.

Ladányi J., Szelényi I. (2004): A kirekesztettség változó formái. Napvilág Kiadó, Budapest

Leonard, R., Onyx, J. (2003): Networking Through Loose and Strong Ties: An Australian Qualitative Study. International Journal of Voluntary and Nonprofit Organizations, 2., 189-203. https://doi.org/ 10.1023/A:1023900111271

Levin, M. (2012): Academic Integrity in Action Research. Action Research, 2., 133-149. https://doi.org/ $10.1177 / 1476750312445034$

Lipsky, M. (1969): Toward a Theory of Street-Level Bureaucracy. IRP Discussion Papers, 48-69. 
Ludwig, J., Duncan, G., Hirschfield, P. (2011): Urban Poverty and Juvenile Crime: Evidence from a Randomized Housing-Mobility Experiment. American Journal of Epidemiology, 11., 655-679. https://doi.org/10.1162/00335530151144122

Lupton, R., Heath, N., Clarke, A., Whitehead, C., Monk, S., Geddes, M., Fullel, C., Tunstall, R., Hayden, C., Robinson, J., (2009): Evaluation of the Mixed Communities Initiative Demonstration Projects: Baseline Reports. Department for Communities and Local Government, London

Málovics, Gy., Méreiné Berki, B., Pataki, Gy., Juhász, J., Pálné Mihók, B., Szentistványi, I., Nagy, M., Tóth, J. (2018): Confronting espoused theories with theories-in-use: Challenges of participatory action research (PAR) with marginalized communities in contributing to social change and theory building. Action Research http://journals.sagepub.com/doi/abs/10.1177/1476750318774389 https:// doi.org/10.1177/1476750318774389

Málovics, Gy., Tóth, J., Méreiné Berki, B., Cretan, R. (2019a): Mapping Place Attachment of Segregated Urban Roma Communities through Participatory Action Research in Szeged, Hungary. AREA, 51., 72-83. https://doi.org/10.1111/area.12426

Málovics, Gy., Cretan, R., Méreiné Berki, B., Tóth, J. (2019b): Socio-environmental justice, participatory development, and empowerment of segregated urban Roma: Lessons from Szeged, Hungary. Cities, 91., 137-145. https://doi.org/10.1016/j.cities.2018.11.013

Málovics Gy. (2019): Tudás létrehozása társadalmi hatással karöltve: a részvételi akciókutatás (RAK) megközelítése. Magyar Tudomány, 8., 1147-1157. https://doi.org/10.1556/2065.180.2019.8.5

May. P., Winter, S.C. (2009): Politicians, managers and street-level bureaucrats: influence on policy implementation. Journal of Public Administration Research and Theory, 3., 453-476. https:// doi.org/10.1093/jopart/mum030

Méreiné Berki B. (2017): Szegénység elleni küzdelem a részvételi akciókutatás segítségével. In: Fodorné Tóth K. (szerk.): Felsőoktatás, életen át tartó tanulás és az ENSZ fenntartható fejlesztési célok megvalósitása/ Higher Education, Lifelong Learning and Implementation of UN Sustainable Development Goals. 198-208.

Méreiné Berki B., Málovics Gy., Juhász J. (2017): A hazai antiszegregációs tervek értékelése Amartya Sen képességszemlélete alapján. In: Bajmócy Z., Gébert J., Málovics Gy. (szerk.): Helyi gazdaságfejlesztés a képességszemlélet alapján. JATEPress, Szeged, 137-160.

Méreiné Berki, B., Málovics, Gy., Tóth, J., Cretan, R. (2017): The role of social capital and interpersonal relations in the alleviation of extreme poverty and spatial segregation of Romani people in Szeged. Journal of Urban and Regional Analysis (JURA), 1., 33-50.

Messing V., Molnár E. (2011a): Válaszok a pénztelenségre: szegény cigány és nem cigány családok megélhetési stratégiái. Esély, 1., 53-80. http://esely.org/kiadvanyok/2011_1/03messingmolnar.indd.pdf (Letöltés: 2018. október 21.)

Messing V., Molnár E. (2011b): Bezáródó kapcsolati hálók: szegény roma háztartások kapcsolati jellemzői. Esély, 5., 47-74. http://www.esely.org/kiadvanyok/2011_5/04molnar.indd.pdf (Letöltés: 2018. október 21.)

Messing V. (2006): Lyukakból szőtt háló: háztartások közötti támogató kapcsolatok roma és nem roma szegények körében. Szociológiai Szemle, 2., 37-54.

Mihály M. (2019): Újratermelődő „gettók”? - A helyi fejlesztés lehetőségei és korlátai egy szélsőségesen marginalizált kistelepülésen. Tér és Társadalom, 4., 132-156. https://doi.org/10.17649/ TET.33.4.3179

Monk, S., Clarke, A., P. Y. Tang, (2011): Housing, regeneration and planning. Mixed communities literature review. Scottish Government Social Research, Edinbrugh

Mugnano, S., Palvarini, S. (2013): "Sharing space without hanging together": A case study of social mix policy in Milan. Cities, 35., 417-422. https://doi.org/10.1016/j.cities.2013.03.008

Nast, J., Blokland, T. (2014): Social Mix Revisited: Neighbourhood Institutions as Setting for Boundary Work and Social Capital. Sociology, 3., 482-499. https://doi.org/10.1177/0038038513500108

Oreopoulos, P. (2003): The Long-Run Consequences of living in a Poor Neighbourhood', Quarterly Journal of Economics, 4., 1533-1575. https://doi.org/10.1162/003355303322552865

Pataki Gy., Bodorkós B., Balázs B., Bela Gy., Kelemen E., Kohleb N. (2011): A vidékfejlesztés demokratizálásának lehetősége: részvételi akciókutatás a Mezőcsáti Kistérségben. In: Pataki Gy., Vári A. (szerk.): Részvétel - akció - kutatás. MTA Szociológiai Kutatóintézet, Budapest, 9-27. 
Pretty J. (2003), Social capital and the collective management of resources. Science, 302 (5652)., 1912-1914. https://doi.org/10.1126/science.1090847

Putnam, R. D. (1993): Making democracy work: Civic traditions in modern Italy. Princeton University Press. Princeton, New Jersey https://doi.org/10.1515/9781400820740

Putnam, R. D. (1995): Bowling alone: America's declining social capital. Journal of Democracy 1., 65-78. https://doi.org/10.1353/jod.1995.0002

Rácz A. (2014): Szegregáció a fejekben. A statisztikai és a mentális társadalmi-és térbeli elkülönülés vizsgálata Szegeden. Doktori (PhD) értekezés, Budapesti Corvinus Egyetem, Szociológia Doktori Iskola, Budapest

Rátkai Á. (1997): A szegedi etnikai közösségek. Eurotrio, Mutatványszám, 28-36.

Silver, H. (2013): Mixing Policies: Expectations and Achievements. Cityscape: A Journal of Policy Development and Research, 2., 73-82.

Silverman, A., Lupton, R., Fenton, A. (2006): A Good Place for Children? Attracting and Retaining Families in Inner Urban Mixed Income Communities. Joseph Rowntree Foundation, York

Solon, G., Page, M., Duncan, G. (2000): Correlations between neighboring children in their subsequent educational attainment. Review of Economics and Statistics, 82., 383-392. https://doi.org/10.1162/ 003465300558885

Sommerville-Steele (2002): 'Race', Housing and Social Exclusion. European Journal of Social Work, 3., 130-149. https://doi.org/10.1080/03069887700760181

Szalai J. (2002): A társadalmi kirekesztés egyes kérdései az ezredforduló Magyarországán. Szociológiai Szemle, 4., 34-51.

Tóth J., Méreiné Berki B., Málovics Gy., Juhász J., Boros L. (2017): "Ha csak úgy kiköltöztetjük az embereket, egymás nélkül elvesznek.” Erőforrások, korlátok és ezek térbelisége a roma szegregátumokban lakók számára: egy hazai város példája. Tér és Társadalom, 3., 62-84. https:// doi.org/10.17649/TET.31.3.2859

Tunstall, R., Lupton, R. (2010): Mixed Communities: Evidence Review, DCLG, London

NFGM (2009): Városfejlesztési Kézikönyv. Nemzeti Fejlesztési és Gazdasági Minisztérium Területfejlesztésért és Építésügyért Felelős Szakállamtitkárság, Budapest

Uitemark, J. (2003): 'Social Mixing' and the Management of Disadvantaged Neighbourhoods: The Dutch Policy of Urban Restructuring Revisited. Urban Studies, 3., 531-49. https://doi.org/ 10.1080/0042098032000053905

Virág T. (2018): A kapcsolathálózatok szerepe a migrációban egy cigányfalu perspektívájából. https://doi.org/10.18030/socio.hu.2018.1.163

Wacquant, L. (2012): A Janus-faced institution of ethnoracial Closure: A Sociological Specification of the ghetto. In: Hutchinson R., Haynes B. D. (ed.): The ghetto. Contemporary global issues and controversies. Westview Press, Boulder, Colo, 1-32. https://doi.org/10.4324/9780429496516-1

Woolcock, M., Narayan, D. (2000): Social Capital: Implications for Development Theory, Research and Policy. World Bank Res. Obs, 15., 225-249. https://doi.org/10.1093/wbro/15.2.225 